\title{
PAINTINGS BY AMERICAN ARTISTS
}

\section{SHITHSOWLE}

LIBRARIES 






\section{Biographical Notes}

The Macbeth Gallery 450 Fifth Avenue New York 
$\$ 25$ 

THE MACBETH GALLERY

\section{Paintings by}

American Artists

$\infty$

Colonial Đortraits

\section{DEC 281992}

William Macbeth

+50 Fifth Avenue

(at Fortieth Street)

New York 



\section{FOREWORD}

In presenting this little collection of Biographical Notes, we have in mind the natural curiosity of the picture collector to know who the man is who painted the picture, and what he has done in the past that may indicate his position in the future.

The list does not pretend to include all the American artists whom we believe to be worth while. The fifty this booklet contains, however, carefully selected from those whose pictures are to be found here, are those for whose reputation an experience of over twenty years enables us to vouch with some degree of certainty.

We extend our thanks to the museums and private collectors who have permitted us to reproduce their canvases, and to the American Art Annual, to the various museum catalogues, and to the artists themselves who read and corrected the proof, for the material here presented.

Correspondence relating to the work of any of the men included in this booklet is cordially invited.

WILLIAM MACBETH. 


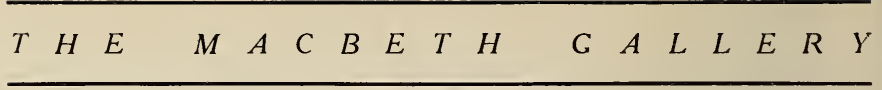

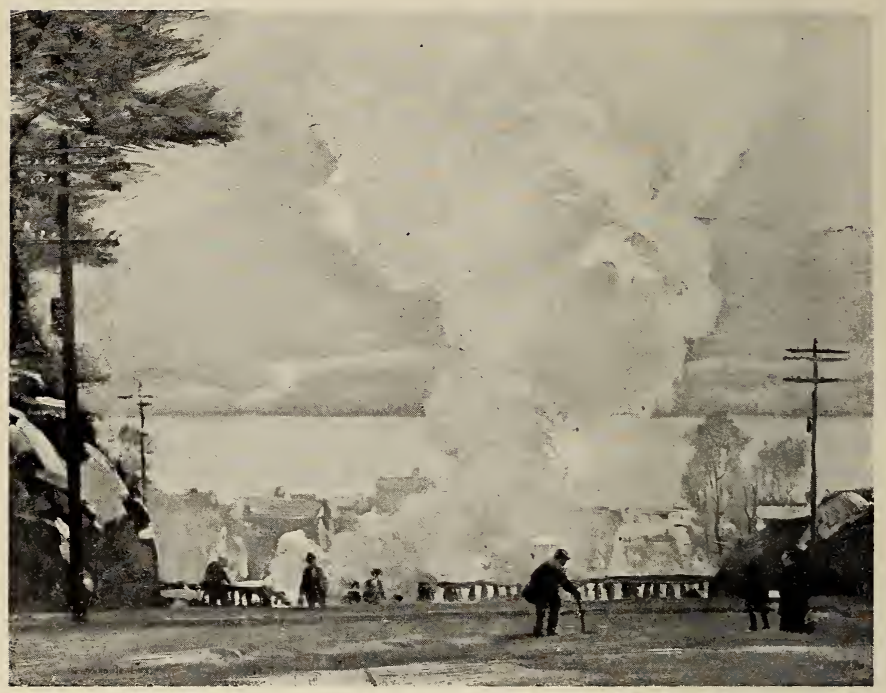

THE PUFF OF SMOKE

-Art Institute of Chicago 


\section{GIFFORD BEAL, N. A.}

New York City. Born, 1879. Member of the American Water Color Society, Lotos Club, Century Association, and of the National Arts Club, New York; Member of the National Academy of Design, New York.

Represented in the Art Institute of Chicago; Metropolitan Museum, New York.

Awarded Third Prize, Worcester Art Museum, 1903; Bronze Medal, Universal Exposition, St. Louis, 1904; First Hallgarten Prize, National Academy of Design, 1910; Honorable Mention, Art Institute of Chicago, 1912; Silver Medal, National Arts Club, 1913; Thomas B. Clarke Prize, National Academy of Design, 1913; Medal of the Third Class, Carnegie Institute, 1913. 


\section{$\begin{array}{llllllllllllllllll}T & H & E & & M & A & C & B & E & T & H & G & A & L & L & E & R & Y\end{array}$}

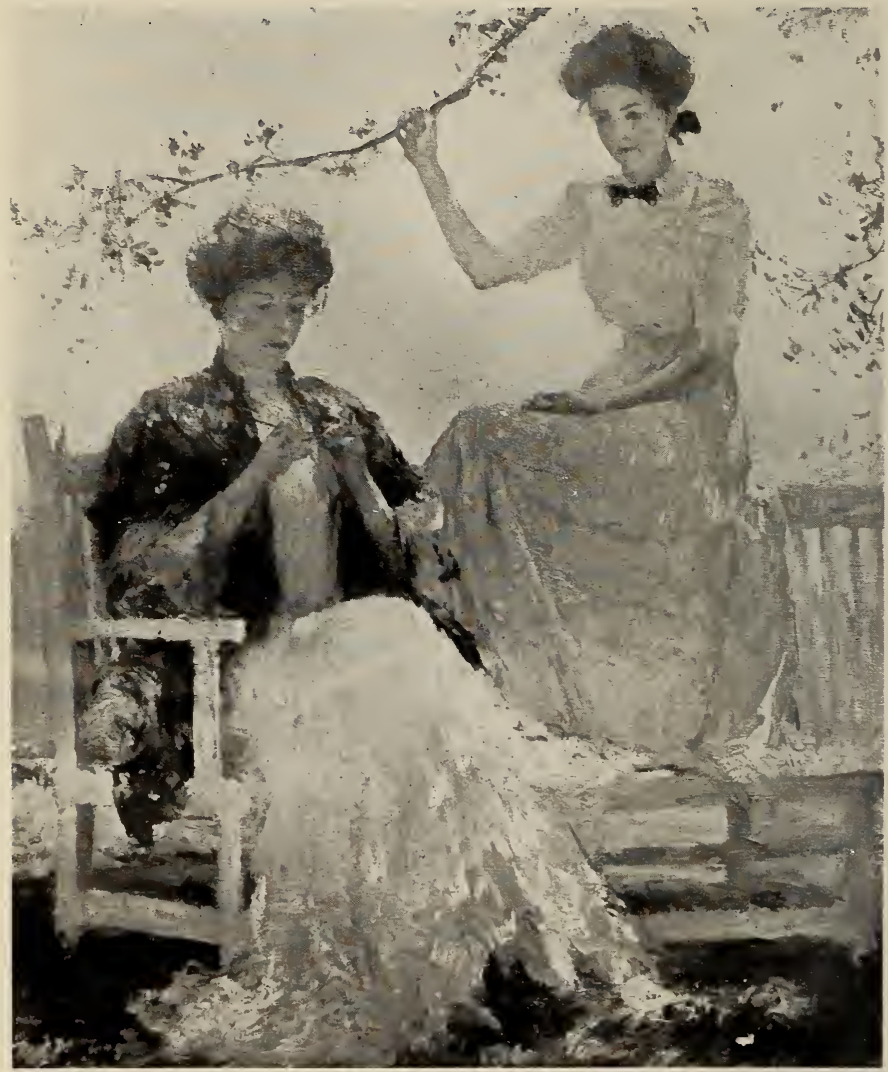

SUNSHINE AND SHADOW

-Privately Owned 


$\begin{array}{llllllllllllllllll}T & H & E & M & A & C & B & E & T & H & G & G & A & L & L & E & R & Y\end{array}$

FRANK W. BENSON, N. A.

Salem, Massachusetts. Born, Salem, Mass., March 24, 1862. Pupil of Boston Art School; Boulanger and Lefebvre, Paris. Member of the National Academy of Design, National Institute of Arts and Letters, and of the Ten American Painters, New York.

Represented in the Metropolitan Museum of Art, New York; City Art Museum, St. Louis; Cincinnati Museum; Rhode Island School of Design, Providence; Carnegie Institute, Pittsburgh; Mural Paintings, Library of Congress, Washington, D. C.

Awarded Third Hallgarten Prize, National Academy of Design, 1889; Thomas B. Clarke Prize, National Academy of Design, 1891; Medal, Columbian Exposition, Chicago, 1893; Shaw Prize, Society of American Artists, 1896; Chronological Medal, Carnegie Institute, 1896; Medal of the Second Class, Carnegie Institute, 1899; Silver Medal, Exposition Universelle, Paris, 1900; Silver Medal, Pan-American Exposition, Buffalo, 1901; Walter Lippincott Prize, Pennsylvania Academy of the Fine Arts, Philadelphia, 1903; Medal of the First Class, Carnegie Institute, 1903; Gold Medal, Art Club of Philadelphia; Temple Gold Medal, Pennsylvania Academy of the Fine Arts, 1908; Norman Wait Harris Silver Medal, Art Institute of Chicago, 1909; Potter Palmer Gold Medal, Art Institute of Chicago, 1912. 


\begin{tabular}{llllllllllllllllll}
\hline & $H$ & $E$ & & $M$ & $A$ & $C$ & $B$ & $E$ & $T$ & $H$ & & $G$ & $A$ & $L$ & $L$ & $E$ & $R$
\end{tabular}

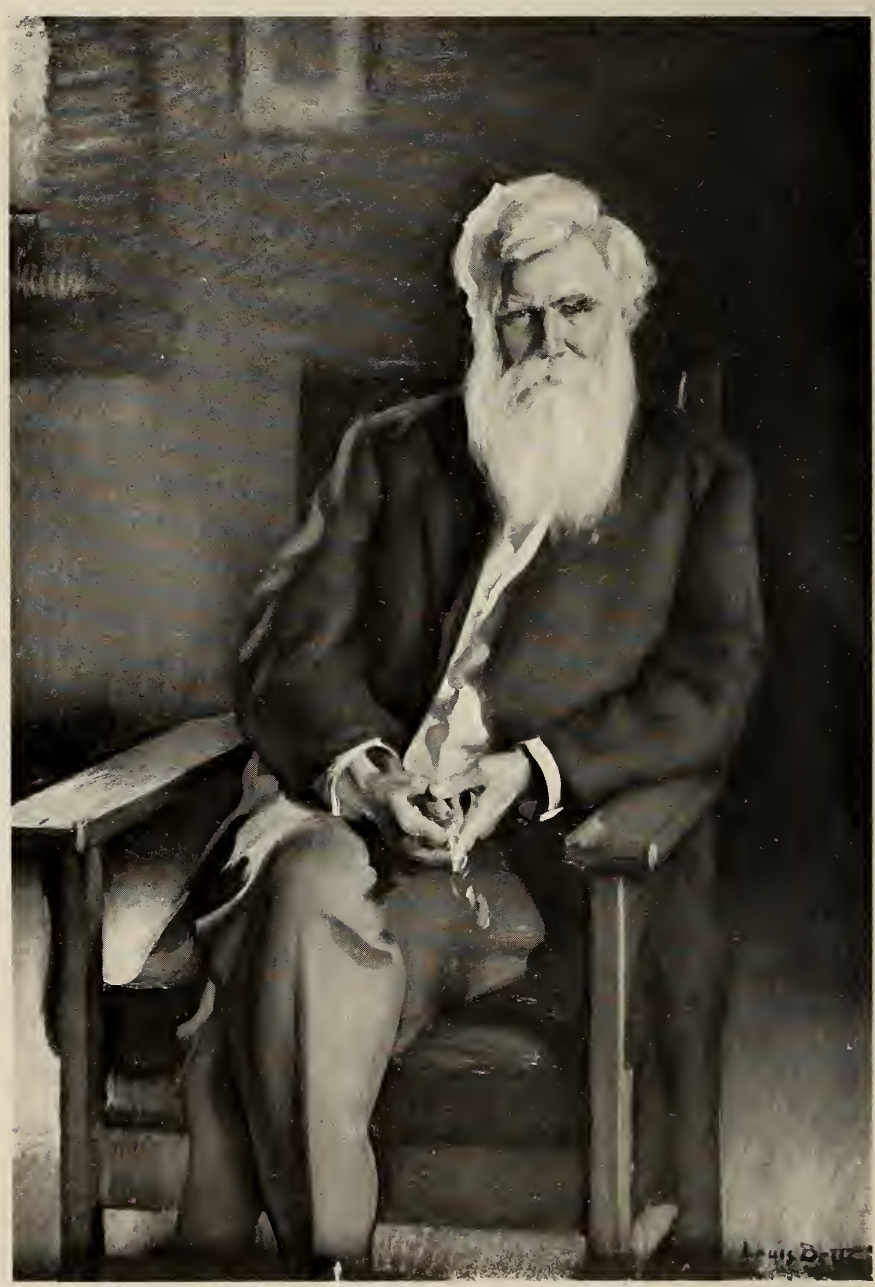

PORTRAIT OF JENKIN LLOYD JONES

-Prizately Ozened 


\section{$\begin{array}{lllllllllllllllllll}T & H & E & & M & A & C & B & E & T & H & G & A & L & L & E & R & Y\end{array}$}

\section{LOUIS BETTS, A. N. A.}

Chicago, Illinois. Born, Little Rock, Arkansas, 1873. Studied at the Art Institute of Chicago and the Pennsylvania Academy of the Fine Arts, and under Wm. M. Chase in New York. Associate of the National Academy of Design, New York; member of the National Institute of Arts and Letters, New York.

Represented in the Art Institute of Chicago; University of Chicago; Armour Institute, Chicago; National Academy of Design, New York.

Awarded Cresson Scholarship, Pennsylvania Academy of the Fine Arts, 1903; Honorable Mention, Carnegie Institute, Pittsburgh, 1910. 


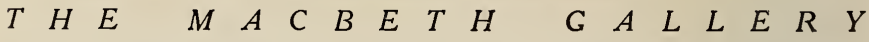

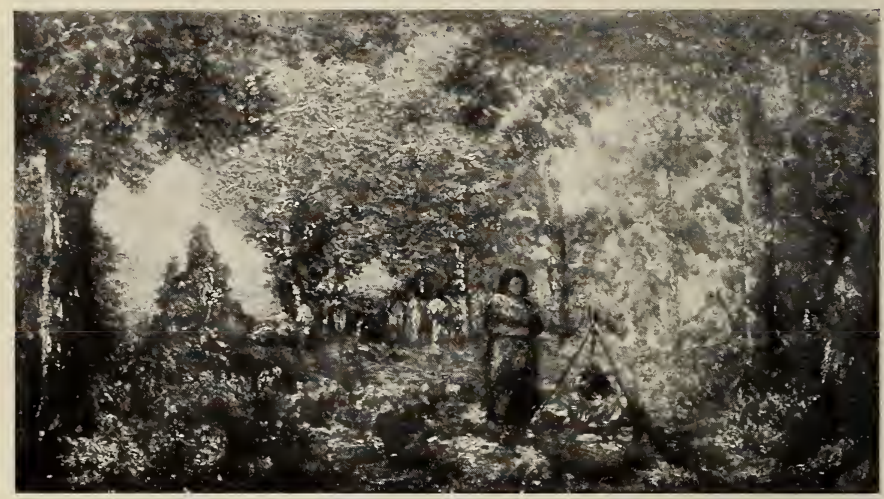

INDIAN ENCAMPMENT 


\section{RALPH A. BLAKELOCK, A. N. A.}

Born, New York City, October 15, 1847. Son of a physician and intended by his parents for medical profession, but his love of painting and music led him to become an artist. Was almost wholly self-taught. A trip to the Far West, where he studied the life of the Indians, gave him the material for many of his best pictures.

Represented in Corcoran Gallery, Washington, D. C.; Worcester Art Museum; National Gallery, Washington, D. C.; Institute of Arts and Sciences, Brooklyn, N. Y.; Hackley Gallery, Muskegon, Mich.; and the Metropolitan Museum of Art, New York.

Awarded Honorable Mention, International Exposition, Paris, 1900; Elected Associate, National Academy of Design, 1912. 


\begin{tabular}{llllllllllllllllll}
$T$ & $H$ & $E$ & $M$ & $A$ & $C$ & $B$ & $E$ & $T$ & $H$ & $G$ & $G$ & $A$ & $L$ & $L$ & $E$ & $R$ & $Y$ \\
\hline
\end{tabular}

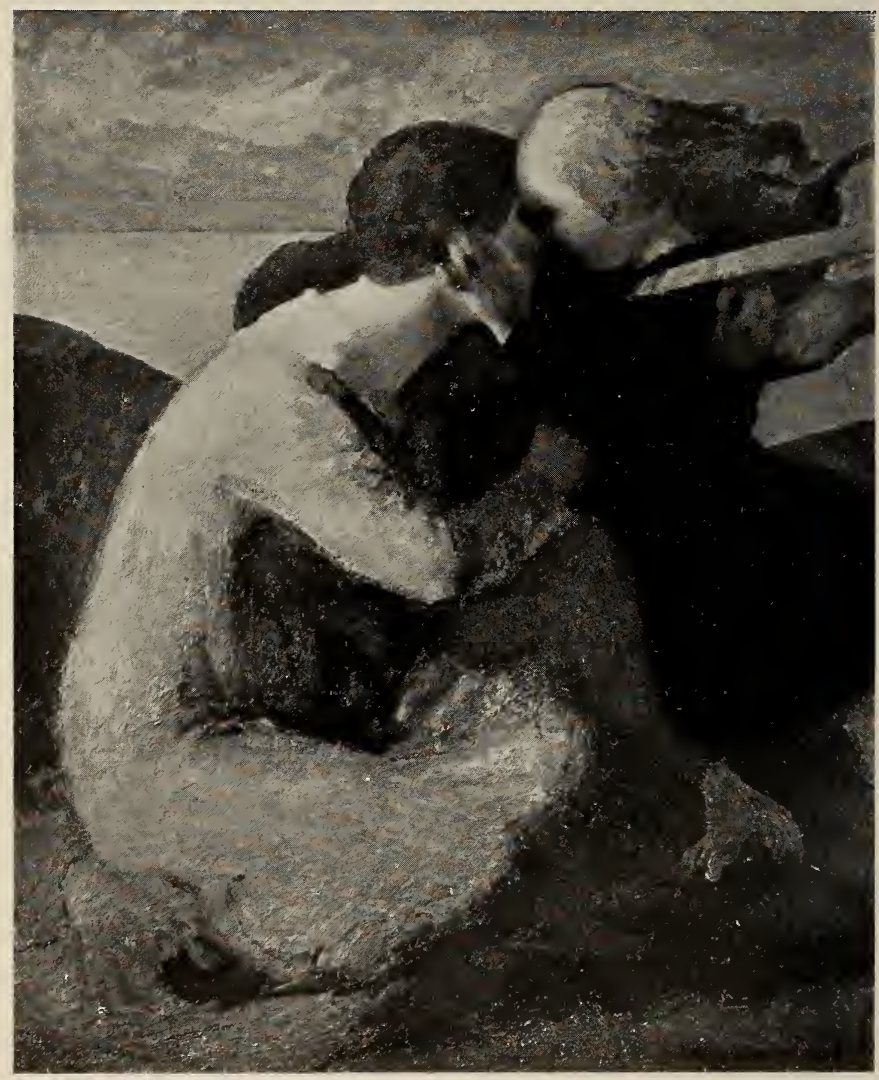

MOTHER AND CHILD 


\section{MAX BOHM}

Paris, France. Born, Cleveland,O., Jan. 21, 1868. Pupil of Laurens, Guillemet, and Constant, Paris. Member of Paris Society of American Artists, also Paris-American Art Association. Member of European Advisory Committee for the Panama Pacific Exposition, San Francisco, 1915.

Represented in the Luxembourg, Paris; Minnesota State Art Society, Minneapolis; Large Mural Decoration in the Court House, Cleveland, Ohio; Portrait of Governor Lind in the Capitol Building, St. Paul, Minnesota.

Awarded Medal, Salon, Paris, 1898; Silver Medal, Exposition Universelle, Paris, 1900; Medal, Pan-American Exposition, Buffalo, 1901; Silver Medal, Universal Exposition, St. Louis, 1904. 


$\begin{array}{llllllllllllllllll}T & H & E & & M & A & C & B & E & T & H & G & A & L & L & E & R & Y\end{array}$

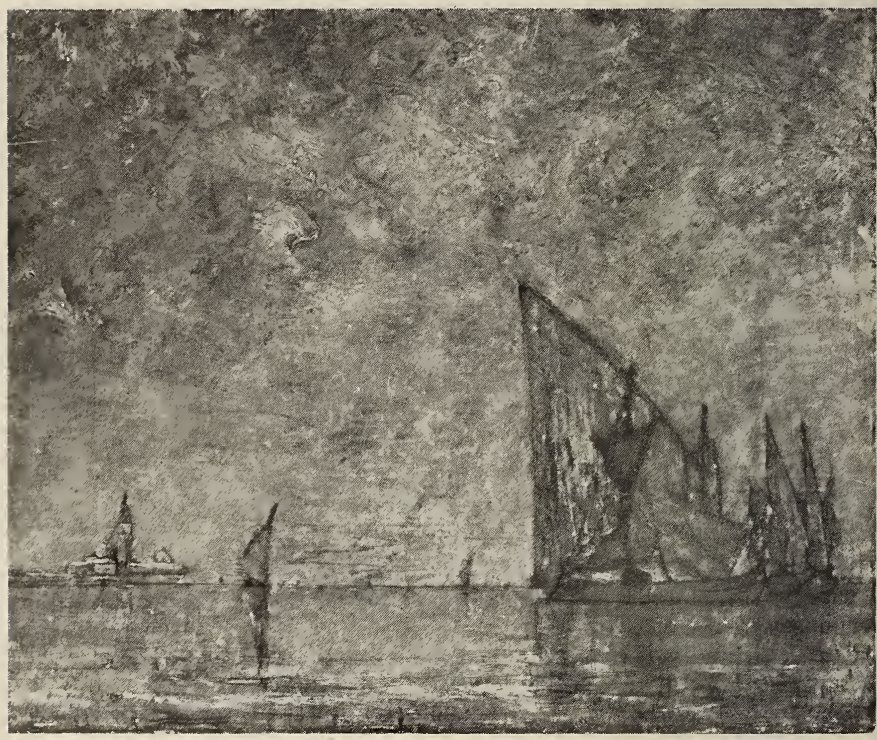

MORNING IN VENICE

-Privately Oroned 
$\begin{array}{llllllllllllllllll}T & H & E & & M & A & C & B & E & T & H & G & G & L & L & E & R & Y\end{array}$

\section{WM. GEDNEY BUNCE, N. A.}

Hartford, Conn. Born, Hartford, Conn., Sept. 14, 1840. Pupil of Cooper Union and of William Hart, New York; Achenbach, Munich; P. J. Clays, Antwerp. Elected Associate, National Academy of Design, 1902; Academician, 1907. Member, National Institute of Arts and Letters.

Represented in Metropolitan Museum, New York; National Gallery, Washington, D. C.

Awarded Bronze Medal, Paris Exposition, 1900; Silver Medal, Pan American Exposition, Buffalo, 1901; Silver Medal, Charleston Exposition, 1902; Silver Medal, St. Louis Exposition, 1904. 


\section{$\begin{array}{llllllllllllllllll}T & H & E & & M & A & C & B & E & T & H & G & A & L & L & E & R & Y\end{array}$}

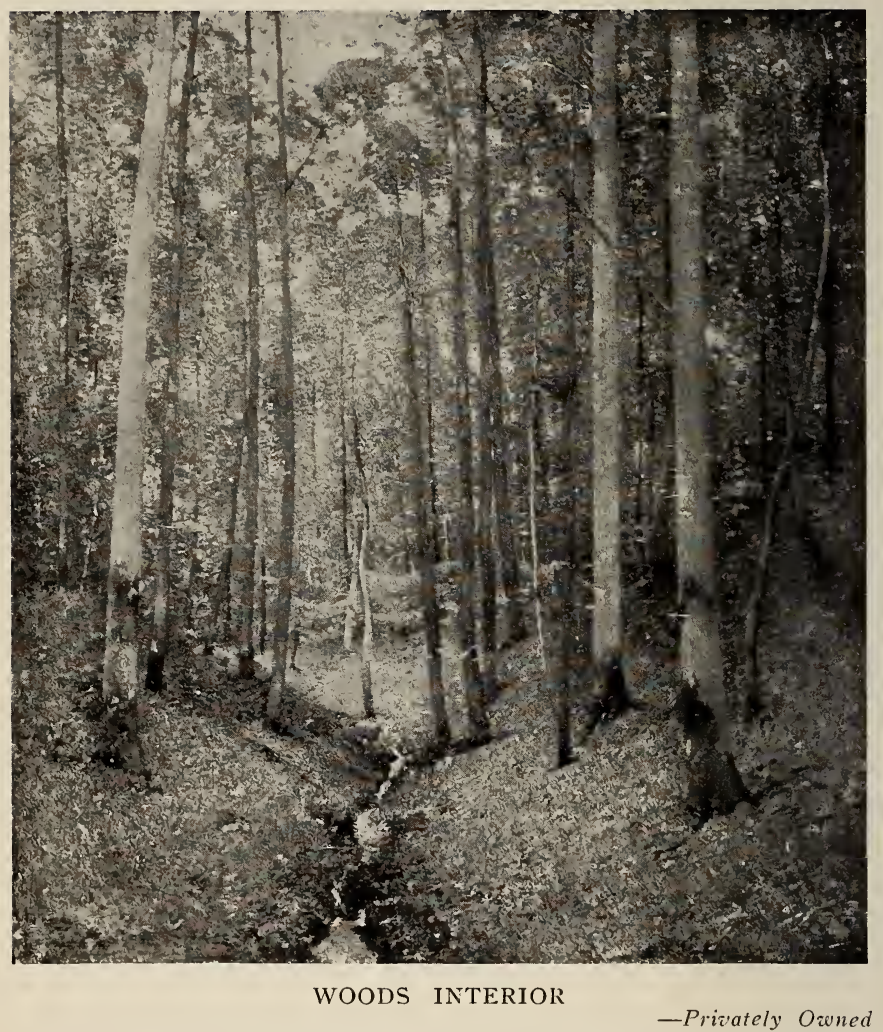




\section{$\begin{array}{llllllllllllllllll}T & H & E & & M & A & C & B & E & T & H & G & A & L & L & E & R & Y\end{array}$}

\section{EMIL CARLSEN, N. A.}

New York City. Born, Copenhagen, Denmark, Oct. 19, 1853. Came to United States, 1872. Studied, Danish Royal Academy. Member of the National Academy of Design, and of the National Institute of Arts and Letters, New York.

Represented in the Metropolitan Museum of Art, New York; Brooklyn Institute of Arts and Sciences; National Gallery of Art, Washington, D. C.; Albright Art Gallery, Buffalo; Rhode Island School of Design, Providence; Art Museum, Minneapolis, Minn.; Art Institute of Chicago; Pennsylvania Academy of the Fine Arts, Philadelphia; Engineers' Club, New York; Lotos Club, New York.

Awarded Samuel T. Shaw Prize, Society of American Artists, New York, 1904; Gold Medal, Universal Exposition, St. Louis, 1904; Webb Prize, Society of American Artists, 1905; Inness Gold Medal, National Academy of Design, 1907; Medal of the Third Class, Carnegie Institute, Pittsburgh, 1908; Bronze Medal, Pennsylvania Academy of the Fine Arts, 1912; Walter Lippincott Prize, Pennsylvania Academy of the Fine Arts, 1913. 


$\begin{array}{llllllllllllllllll}T & H & E & & M & A & C & B & E & T & H & G & A & L & L & E & R & Y\end{array}$

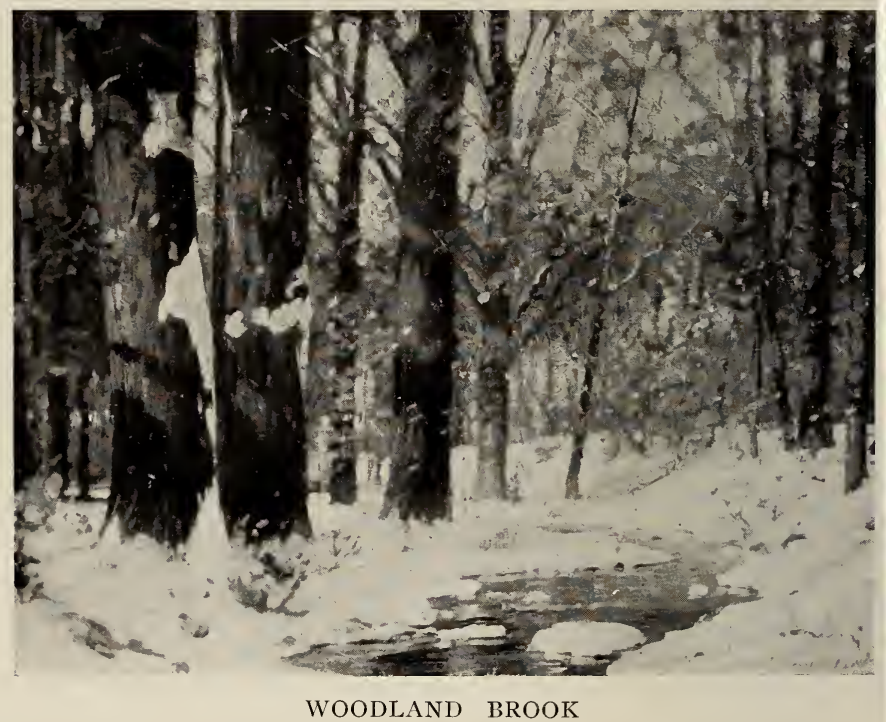




\section{JOHN F. CARLSON, A. N. A.}

Woodstock, N. Y. Born, Kalmar Län, Sweden, 1875. Associate Member of the National Academy of Design; Member New York Water Color Club; Salmagundi Club.

Represented in the Corcoran Gallery, Washington, D. C.

Awarded First Prize, Swedish American Exhibition, Chicago, 1911 and 1913; Silver Medal, Washington Society of Artists, 1913; First Isidore Prize, Salmagundi Club, 1912; Vezin Prize, Salmagundi Club, 1912. 


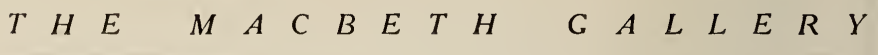

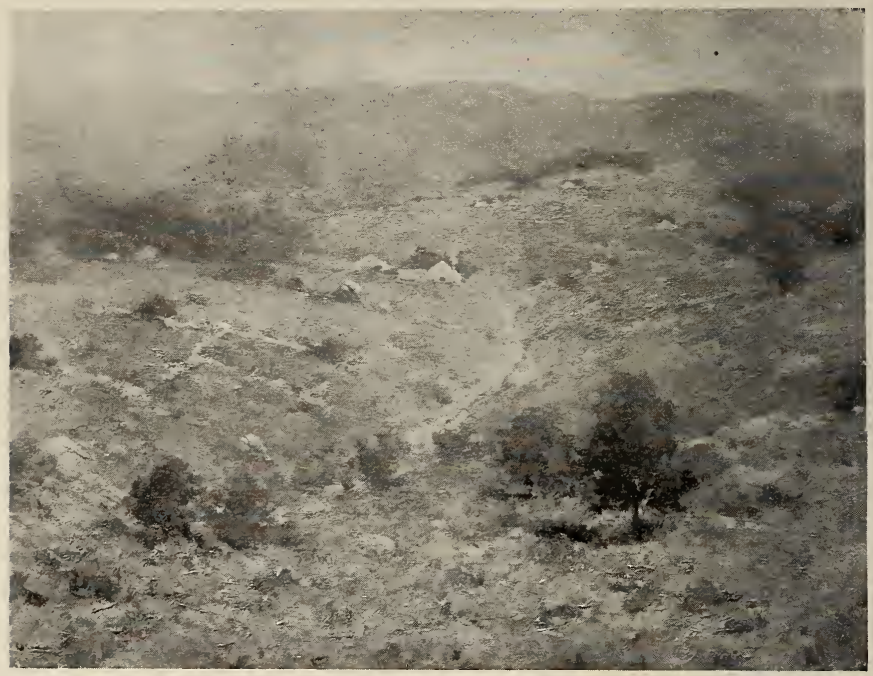

CLEARING OFF

-Metropolitan Museum 


$\begin{array}{llllllllllllllllll}T & H & E & M & A & C & B & E & T & H & G & A & L & L & E & R & Y\end{array}$

CHARLOTTE B. COMAN, A. N. A.

New York City. Born Waterville, N. Y., 1833. Pupil of James R. Brevoort in New York; Harry Thompson and Emil Vernier in Paris. Elected Associate of the National Academy of Design, 1910; Member New York Water Color Club; Art Workers' Club; Association of Women Painters and Sculptors, New York.

Represented in Metropolitan Museum, New York; National Gallery, Washington.

Awarded Bronze Medal, California Mid-Winter Exposition, San Francisco, 1894; Prize, New York Woman's Art Club; Shaw Memorial Prize, Society of American Artists, 1905; Second Prize, Society of Washington Artists, 1906; Burgess Prize, New York Woman's Art Club, 1907; McMillin Prize, New York Woman's Art Club, 1911. 


\section{$\begin{array}{llllllllllllllllll}T & H & E & & M & A & C & B & E & T & H & G & A & L & L & E & R & Y\end{array}$}

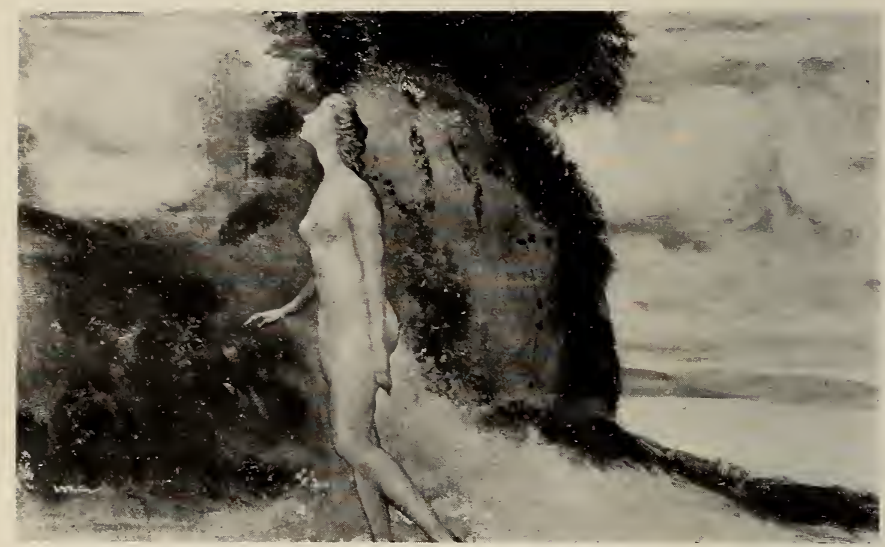

A DREAM

-Metropolitan Museum 


$\begin{array}{llllllllllllllllll}T & H & E & & M & A & C & B & E & T & H & G & G & A & L & L & E & R\end{array}$

\section{ARTHUR B. DAVIES}

New York City. Born, Utica, N.Y., Sept. 26, 1862. Pupil of Dwight Williams of Utica. Studied in New York and Art Institute of Chicago. President of the Society of American Painters and Sculptors, New York, 1913; Member of the New York Water Color Club.

Represented in the Metropolitan Museum of Art, New York; Minneapolis Museum of Art; San Francisco Institute of Art; Brooklyn Institute of Arts and Sciences; Art Institute of Chicago. Awarded Silver Medal, Pan-American Exposition, Buffalo, 1901; Honorable Mention, Carnegie Institute, 1913. 


\section{$\begin{array}{llllllllllllllllll}T & H & E & & M & A & C & B & E & T & H & G & G & A & L & L & E & R\end{array}$}

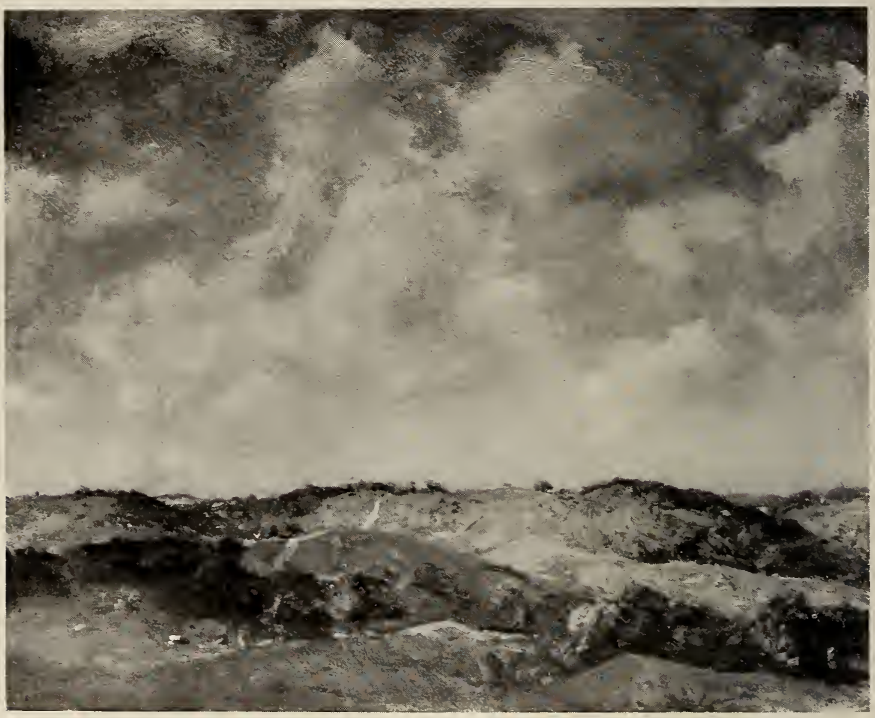

ON THE WEST WIND 


\section{CHARLES H. DAVIS, N. A.}

Mystic, Conn. Born, Amesbury, Massachusetts, Jan. 7, 1856. Pupil of Otto Grundmann and Boston Museum School; Boulanger and Lefebvre, Paris. Member of the National Academy of Design, New York.

Represented in the Pennsylvania Academy of the Fine Arts, Philadelphia; Corcoran Gallery of Art, Washington, D. C.; Metropolitan Museum of Art, New York; Art Institute of Chicago; Wadsworth Athenaeum, Hartford; Art Gallery, Omaha; Boston Art Museum; Art Museum, Syracuse; Art Museum, Cincinnati; City Art Museum, St. Louis; Art Museum, Minneapolis, Minn.; Art Museum, Worcester, Massachusetts; Carnegie Institute, Pittsburgh; Hackley Gallery, Muskegon, Mich.

Honorable Mention, Salon, Paris, 1887; Silver Medal, Exposition Universelle, Paris, 1889; Palmer Prize, Art Institute of Chicago, 1890; Medal, Massachusetts Charitable Mechanics' Association, Boston, 1890; Medal, Columbian Exposition, Chicago, 1893; Grand Gold Medal, Atlanta Exposition, 1895; Gold Medal, American Art Association, New York, 1896; Cash Prize, American Art Association, 1897; Potter Palmer Prize, Art Institute of Chicago, 1898; Bronze Medal, Exposition Universelle, Paris, 1900; Lippincott Prize, Pennsylvania Academy of the Fine Arts, Philadelphia, 1901; Silver Medal, PanAmerican Exposition, Buffalo, 1901; Silver Medal, Universal Exposition, St. Louis, 1904; Hors Concours, Salon, Paris. 


\begin{tabular}{llllllllllllllllll}
\hline$T$ & $H$ & $E$ & $M$ & $A$ & $C$ & $B$ & $E$ & $T$ & $H$ & & $G$ & $A$ & $L$ & $L$ & $E$ & $R$ & $Y$ \\
\hline
\end{tabular}

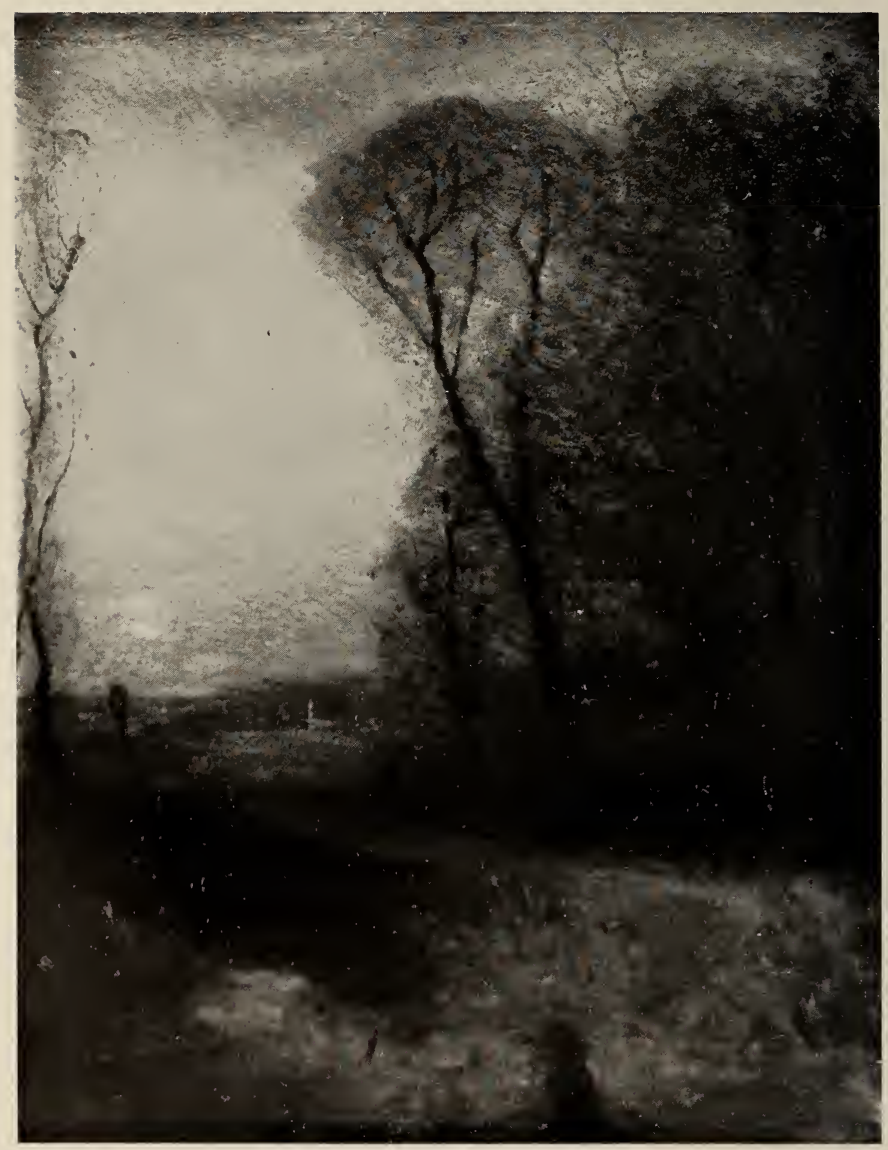

OCTOBER EVENING 
CHAS. MELVILLE DEWEY, N. A.

New York City. Born Lowville, N. Y., July 16, 1849. Pupil of Carolus-Duran in Paris. Elected Associate, National Academy of Design, 1903; Academician, 1907. Member National Institute of Arts and Letters; Lotos Club, New York.

Represented in Corcoran Gallery, Washington, D. C.; Albright Art Gallery, Buffalo, N. Y; National Gallery, Washington, D. C.; Pennsylvania Academy of the Fine Arts, Philadelphia, Pa.; Institute of Arts and Sciences, Brooklyn, N. Y.

Awarded Silver Medal, Pan-American Exposition, Buffalo, 1901; Silver Medal, St. Louis Exposition, 1904. 


\section{$\begin{array}{llllllllllllllllll}T & H & E & M & A & C & B & E & T & H & G & G & A & L & E & R & Y\end{array}$}

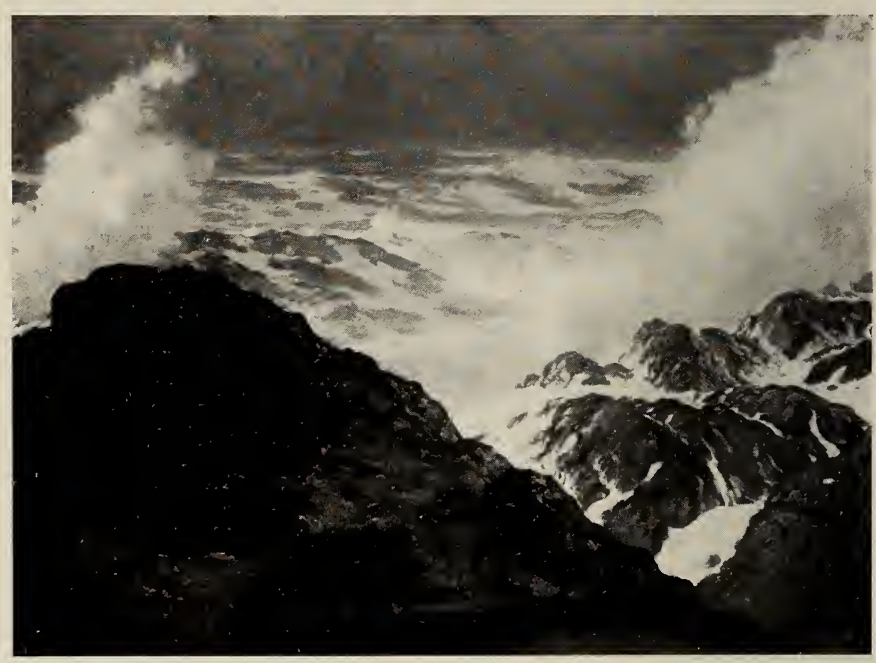

STORM VOICES

-Privately Owned 


\section{PAUL DOUGHERTY, N. A.}

New York City. Born, Brooklyn, N. Y., Sept. 6, 1877. Studied in Paris, London, Florence, Venice and Munich. Member of the National Academy of Design, and of the National Institute of Arts and Letters, New York.

Represented in the National Gallery of Art, and the Corcoran Gallery of Art, Washington, D. C.; Metropolitan Museum of Art, New York; Art Institute of Chicago; Toledo Museum of Art; Brooklyn Institute of Arts and Sciences; Carnegie Institute, Pittsburgh; Portland Art Association, Portland, Oregon; Fort Worth Art Museum, Fort Worth, Texas; Hackley Art Gallery, Muskegon, Michigan; Public Library, Malden, Mass.; City Art Museum, St. Louis, Mo.; Albright Gallery, Buffalo; National Gallery of Canada, Ottawa.

Awarded Silver Medal, Carnegie Institute, 1912; Inness Gold Medal, National Academy of Design, 1913. 


$\begin{array}{llllllllllllllllll}T & H & E & & M & A & C & B & E & T & H & & G & A & L & L & E & R\end{array}$

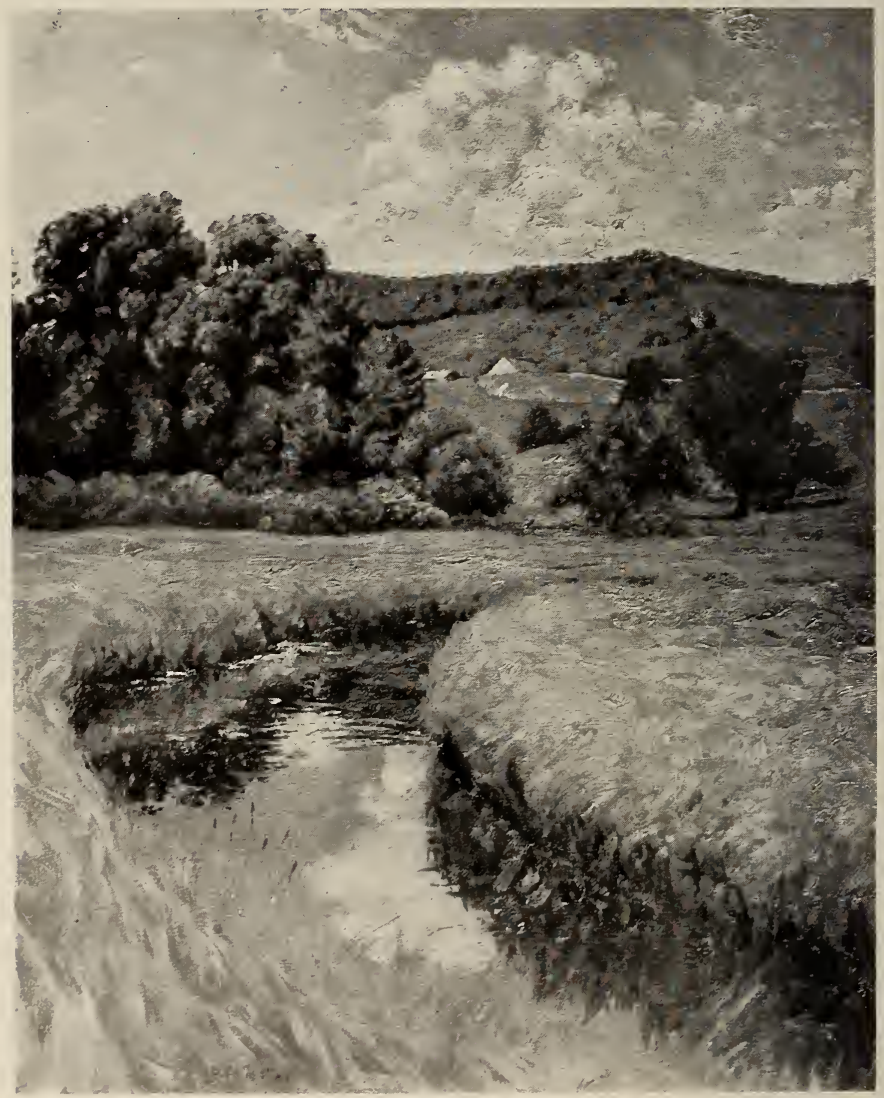

SUMMER DAY 


\section{BEN FOSTER, N. A.}

New York City. Born, North Anson, Maine. Pupil of Abbot H. Thayer, New York; Morot and Merson, Paris. Member of the National Academy of Design, National Institute of Arts and Letters, National Arts Club, Lotos Club, Century Association, MacDowell Club, American Water Color Society, Society of Men Who Paint the Far West, and of the New York Water Color Club.

Represented in Luxembourg, Paris; Art Association of Montreal, Canada; Brooklyn Institute of Arts and Sciences; National Gallery of Art, and the Corcoran Gallery of Art, Washington, D. C.; Pennsylvania Academy of the Fine Arts; City Art Museum, St. Louis; Toledo Museum of Art; Syracuse Museum of Fine Arts; Art Institute of Chicago; Metropolitan Museum, New York.

Awarded Bronze Medal, Columbian Exposition, Chicago, 1893; Bronze Medal, Exposition Universelle, Paris, 1900; Medal of the Second Class, Carnegie Institute, Pittsburgh, 1900; Silver Medal, Pan-American Exposition, Buffalo, 1901; Webb Prize, Society of American Artists, New York, 1901 ; Silver Medal, Universal Exposition, St. Louis, 1904; Carnegie Prize, National Academy of Design, 1906; Inness Gold Medal, National Academy of Design, 1909. 


\begin{tabular}{llllllllllllllllll}
\hline$T$ & $H$ & $E$ & & $M$ & $A$ & $C$ & $B$ & $E$ & $T$ & $H$ & & $G$ & $A$ & $L$ & $L$ & $E$ & $R$
\end{tabular}

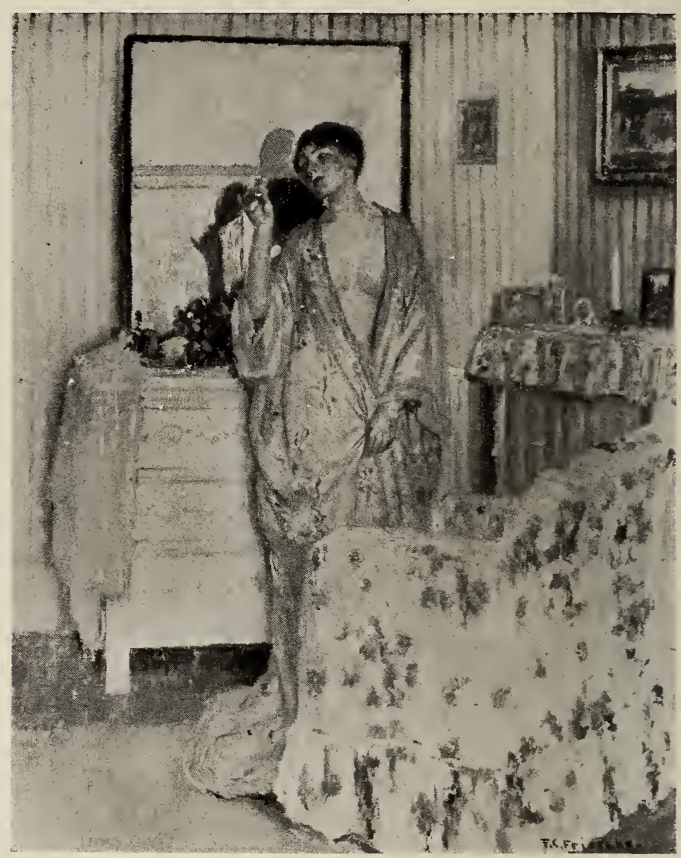

THE TOILET 
$\begin{array}{llllllllllllllllll}T & H & E & & M & A & C & B & E & T & H & G & A & L & L & E & R & Y\end{array}$

FREDERIC C. FRIESEKE, A. N. A.

Paris, France. Born, Owosso, Michigan, April 7, 1874. Pupil of Art Institute of Chicago; Art Students' League, New York; Constant, Laurens and Whistler, Paris. Elected Associate of National Academy of Design, 1912. Member of the Société Nationale des Beaux Arts, Society of American Artists, and Société Internationale, Paris.

Represented in the Luxembourg, Paris; Metropolitan Museum, New York; Telfair Academy of the Arts and Sciences, Savannah; Modern Gallery, Venice; Museum of Odessa; Art Museum, Minneapolis, Minn.; Art Institute of Chicago; Syracuse Museum of Fine Arts.

Awarded Gold Medal, International Art Exhibition, Munich, 1904; Silver Medal, Universal Exhibition, St. Louis, 1904; Fourth W. A. Clark Prize, Corcoran Gallery of Art, Washington, D. C., 1908; Temple Gold Medal, Pennsylvania Academy of the Fine Arts, Philadelphia, 1913. 


\section{$\begin{array}{lllllllllllllllllll}T & H & E & & M & A & C & B & E & T & H & G & G & A & L & L & E & R & Y\end{array}$}

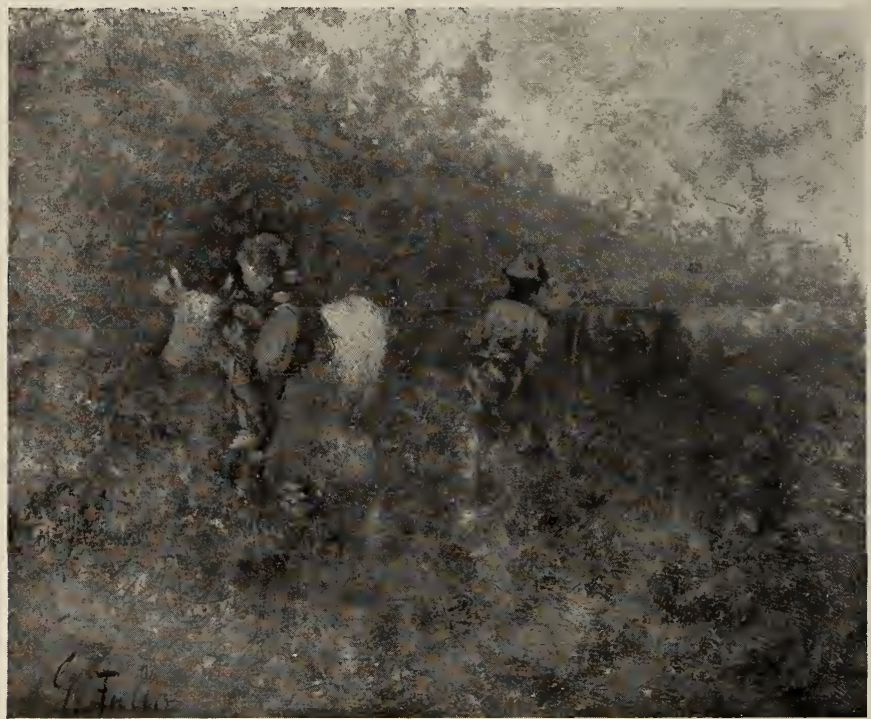

BRINGING HOME THE COWS 


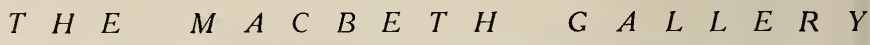

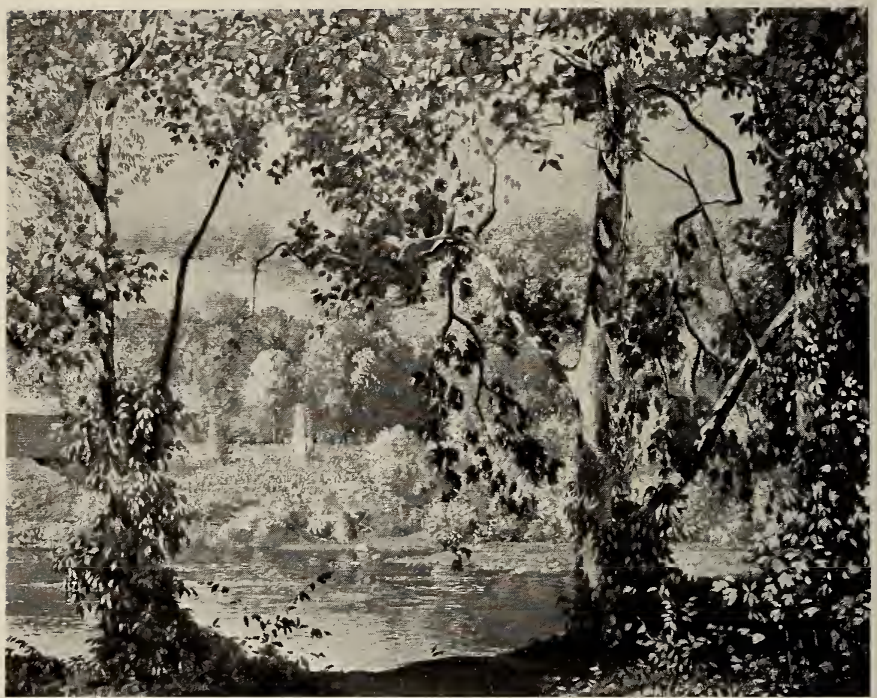

FIELDS IN JERSEY

-Privately Owned 
DANIEL GARBER, N. A.

Philadelphia, Pennsylvania. Born, North Manchester, Indiana, April 11, 1880. Pupil of Cincinnati Art Academy under Nowottny, and under Thomas P. Anshutz at the Pennsylvania Academy of the Fine Arts. Member of the Faculty of the Pennsylvania Academy of the Fine Arts. Member of the National Academy of Design, New York. Member of the Fellowship of the Pennsylvania Academy of the Fine Arts, Philadelphia; Art Club of Philadelphia.

Represented in the Art Institute of Chicago; Cincinnati Museum; Corcoran Gallery of Art, Washington, D. C.; University of Missouri; Ann Brown Memorial, Providence, R. I.; City Art Museum, St. Louis, Mo.

Awarded First Hallgarten Prize, National Academy of Design, 1909; Honorable Mention, Carnegie Institute, 1910; Honorable Mention, Art Club of Philadelphia, 1910; Fourth W. A. Clark Prize and Honorable Mention, Corcoran Gallery of Art, 1910; Bronze Medal, International Exposition, Buenos Aires, 1910; Walter Lippincott Prize, Pennsylvania Academy of the Fine Arts, 1911; Potter Palmer Gold Medal, Art Institute of Chicago, 1911; Second W. A. Clark Prize and Silver Medal, Corcoran Gallery of Art, 1912. 


\begin{tabular}{llllllllllllllllll}
$T$ & $H$ & $E$ & & $M$ & $A$ & $C$ & $B$ & $E$ & $T$ & $H$ & $G$ & $G$ & $A$ & $L$ & $E$ & $R$ & $Y$ \\
\hline
\end{tabular}

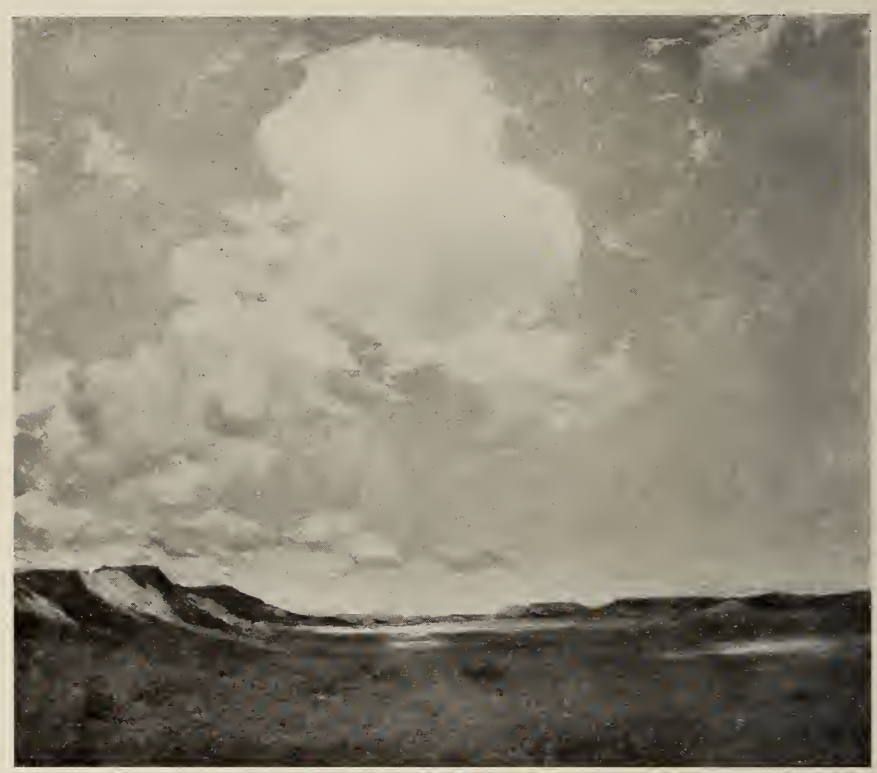

ARIZONA DESERT 


\section{ALBERT L. GROLL, N. A.}

New York City. Born, New York. Pupil of Bavarian Royal Academy, and of Gysis and Loefftz, Munich. Elected Associate of National Academy of Design, 1906; Academician, 1910.

Represented in Metropolitan Museum, New York; Corcoran Gallery, Washington; National Gallery, Washington; St. Paul Museum, St. Paul, Minn.; Brooklyn Institute of Arts and Sciences; Public Gallery, Richmond, Ind.; Lotos Club, New York; Salmagundi Club, New York; Minneapolis Museum, Minneapolis, Minn.

Awarded Morgan Prize, Salmagundi Club, New York, 1903; Honorable Mention, Munich, 1903; Shaw Prize, Salmagundi Club, 1904; Silver Medal, St. Louis Exposition, 1904; Gold Medal, Pennsylvania Academy, 1904; Inness Gold Medal, National Academy of Design, New York, 1912. 


\section{$\begin{array}{lllllllllllllllllll}T & H & E & & M & A & C & B & E & T & H & G & A & L & L & E & R & Y\end{array}$}

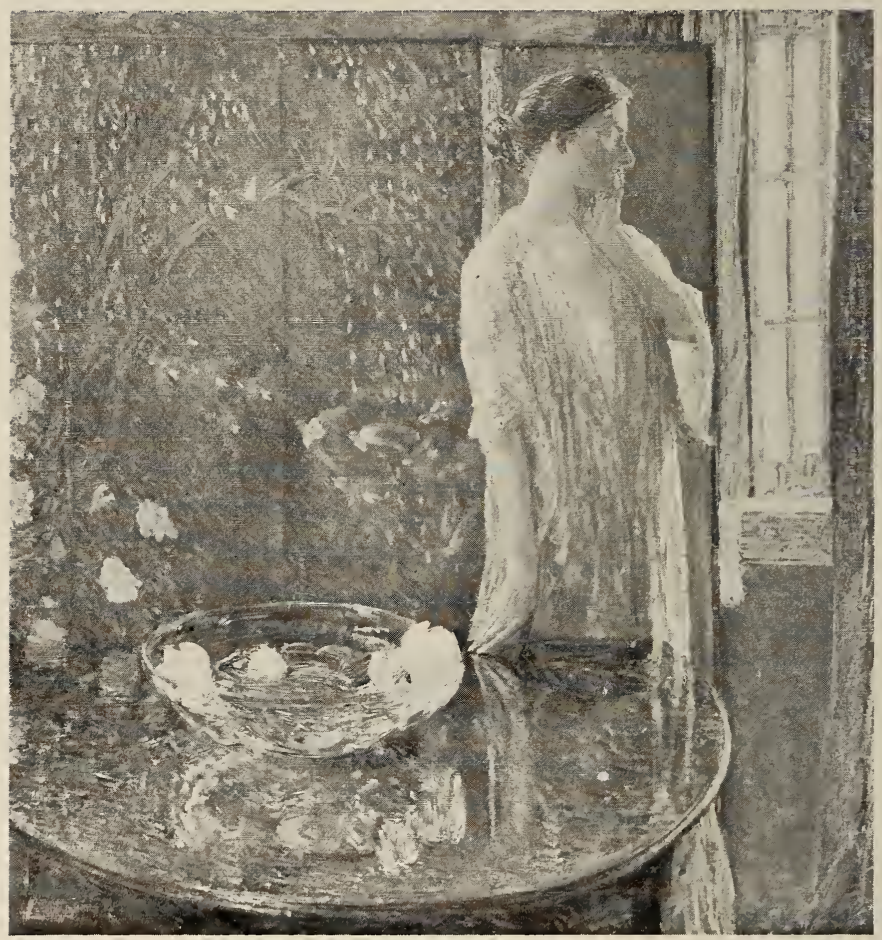

SPRING MORNING

-Owned and Copyrighted by Carnegie Institute, Pittsburgh 


\section{CHILDE HASSAM, N. A.}

New York City. Born, Boston, Mass., 1869. Pupil of Boulanger and Lefebvre, Paris. Member, Ten American Painters, National Academy of Design, American Water Color Society, and New York Water Color Club. Associate, Société Nationale des Beaux Arts, Paris; Secession Society, Munich.

Represented in Boston Art Club; Metropolitan Museum; Albright Gallery, Buffalo; Art Institute, Indianapolis; Telfair Academy, Savannah, Georgia; Cincinnati Art Museum; Peabody Institute, Baltimore; Rhode Island School of Design, Providence; Art Museum, Worcester, Mass.; Art Club of Erie, Pennsylvania; Art Association, Portland, Oregon; Corcoran Gallery of Art, Freer Collection, and National Gallery of Art, Washington, D. C.; Art Association, Muncie, Indiana; Hillyer Art Gallery, Northampton, Mass.; Walters Gallery, Baltimore; Pennsylvania Academy of the Fine Arts, Philadelphia; Carnegie Institute, Pittsburgh.

Awarded Medal of the Third Class, Exposition Universelle, Paris, 1889; Medal of the Second Class, Munich, 1892; Gold Medal, Art Club of Philadelphia, 1892; Medal, Columbian Exposition, Chicago, 1893; Webb Prize, Society of American Artists, New York, 1895; Prize, Boston Art Club, 1896; Medal of the Second Class, Carnegie Institute, 1898; Temple Gold Medal, Pennsylvania Academy of the Fine Arts, 1899; Silver Medal, Exposition Universelle, Paris, 1900; Gold Medal, Pan-American Exposition, Buffalo, 1901; Gold Medal, Universal Exposition, St. Louis, 1904; Medal of the Third Class, Carnegie Institute, 1905; Thomas B. Clarke Prize, National Academy of Design, 1905; Carnegie Prize, Society of American Artists, 1906; Walter Lippincott Prize, Pennsylvania Academy of the Fine Arts, 1906; Sesnan Gold Medal, Pennsylvania Academy of the Fine Arts, 1910; Evans Prize, American Water Color Society, 1912; First W. A. Clark Prize and Corcoran Gold Medal, Corcoran Gallery, Washington, 1912. 


\section{$\begin{array}{llllllllllllllllll}T & H & E & & M & A & C & B & E & T & H & G & G & L & L & E & R & Y\end{array}$}

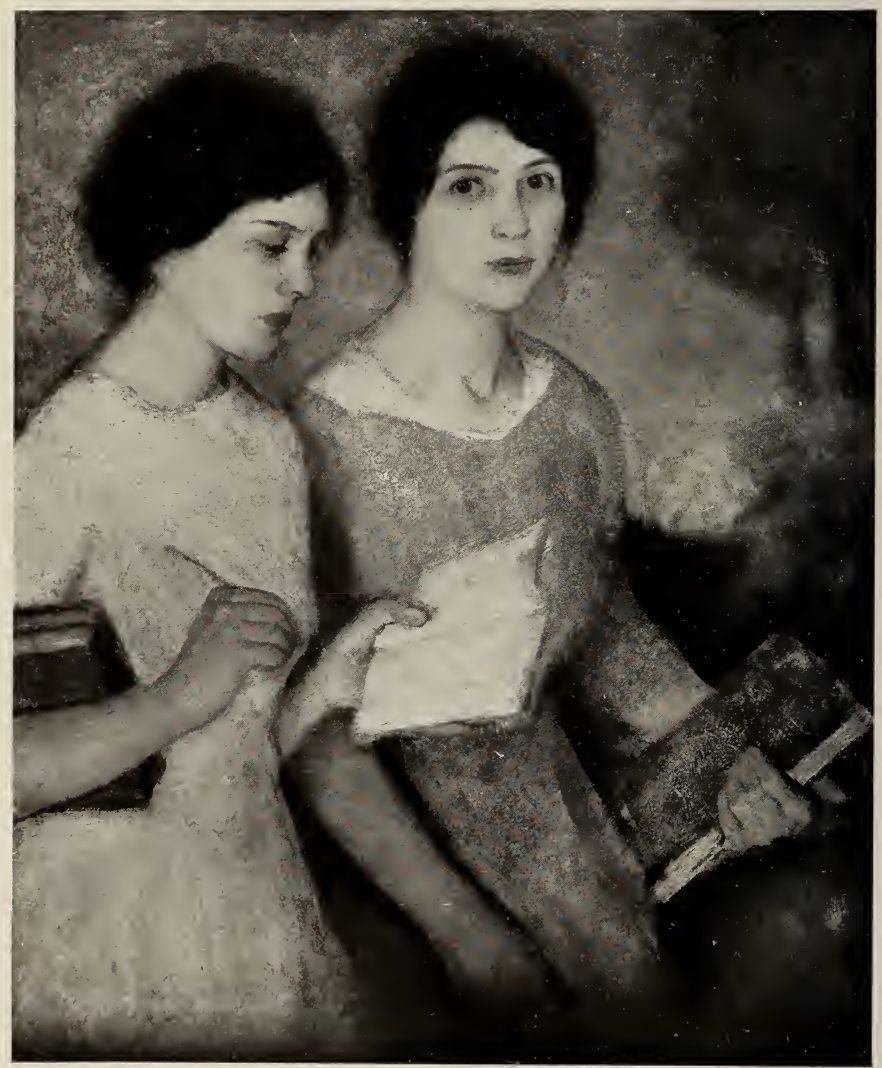

SCHOOLGIRLS

-Privately Owned 
CHARLES W. HAWTHORNE, N. A.

New York City. Born, Maine, June 8, 1872. Pupil of National Academy of Design and Art Students' League, New York; Wm. M. Chase, Shinnecock, L. I. Member of the National Academy of Design, and of the National Arts Club, New York; Associate Member of the Société $\mathrm{Na}$ tionale des Beaux-Arts, Paris.

Represented in the Worcester Art Museum; Rhode Island School of Design, Providence; Metropolitan Museum of Art, New York; Syracuse Museum of Fine Arts, Syracuse, New York; Corcoran Gallery of Art, Washington, D. C.; Chicago Art Institute; Albright Gallery, Buffalo; Peabody Institute, Baltimore, Md.; State Normal School, New Britain, Conn.; Boston Art Club; Engineers' Club, New York; Hackley Gallery, Muskegon, Mich.

Awarded First Hallgarten Prize, National Academy of Design, 1904; Second Prize, Worcester Art Museum, 1903; Second Prize, Worcester Art Museum, 1904; Second Hallgarten Prize, National Academy of Design, 1906; Thomas B. Clarke Prize, National Academy of Design, 1911. 


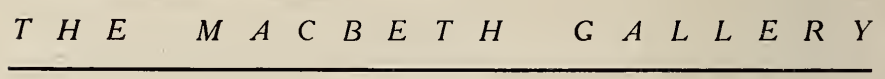

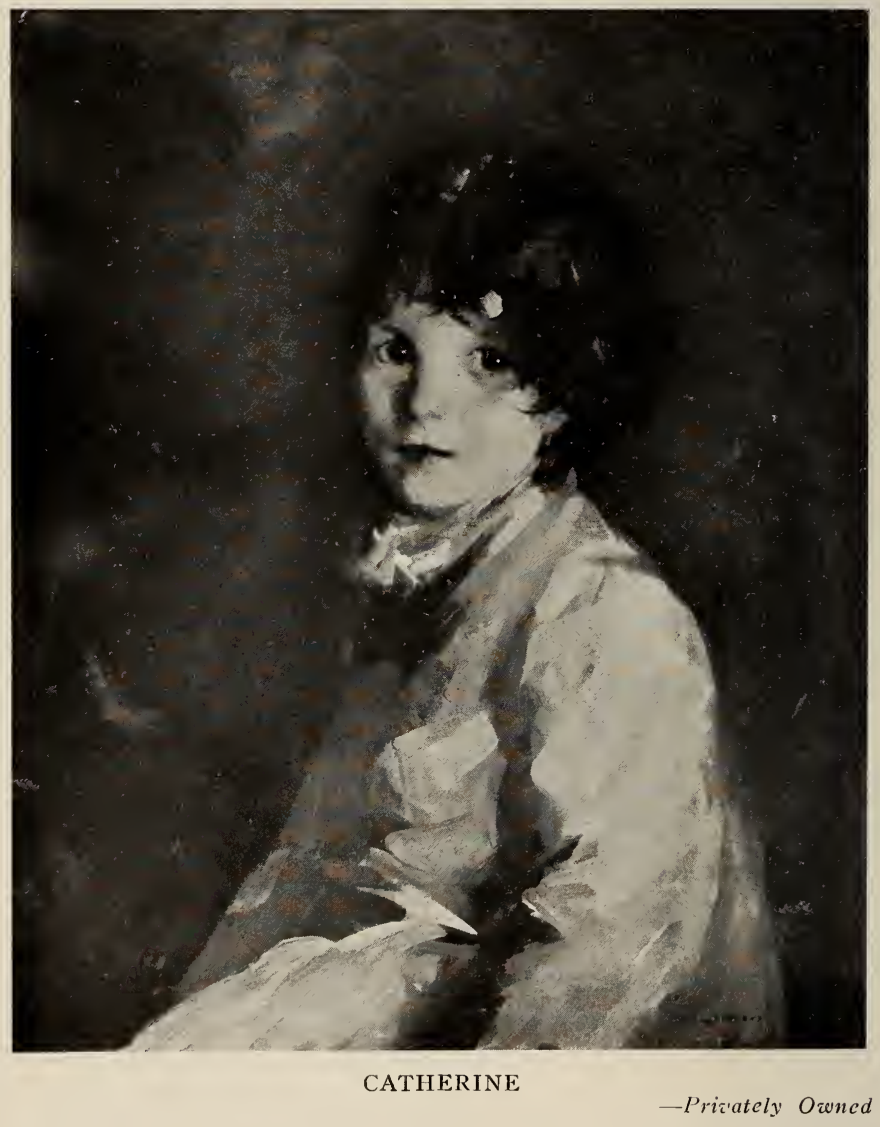




\section{ROBERT HENRI, N. A.}

New York City. Born, June 24, 1865. Pupil of Pennsylvania Academy; Julian Academy and Ecole des Beaux Arts, Paris. Member of the Society of American Artists, National Academy of Design, National Irstitute of Arts and Letters, National Society of Portrait Painters, Association of American Painters and Sculptors, New York; Fellowship of the Pennsylvania Academy of the Fine Arts, Philadelphia; The MacDowell Club of New York; Life Membership, National Arts Club, New York; Municipal Art Society of New York.

Represented in the Luxembourg, Paris; Art Institute of Chicago; Art Association of Dallas, Texas; Columbus Gallery of Fine Arts, Columbus, Ohio; Isaac Delgado Museum of Art, New Orleans; Pennsylvania Academy of the Fine Arts, Philadelphia; Brooklyn Institute of Arts and Sciences; Carnegie Institute, Pittsburgh; Carolina Art Association, Charleston, S. C.; Gallery of Spartanburg, S. C.; Art Institute of Kansas City, Mo.; San Francisco Institute of Art.

Awarded Silver Medal, Pan-American Exposition, Buffalo, 1901; Silver Medal, Universal Exposition, St. Louis, 1904; Harris Silver Medal, Art Institute of Chicago, 1905; Gold Medal, Art Club of Phliadelphia, 1909; Silver Medal, International Exposition, Buenos Aires, 1910; Carol H. Beck Gold Medal, Pennsylvania Academy of the Fine Arts, Philadelphia, Pa., 1914. 


\begin{tabular}{lllllllllllllllllll}
\hline$T$ & $H$ & $E$ & & $M$ & $A$ & $C$ & $B$ & $E$ & $T$ & $H$ & & $G$ & $A$ & $L$ & $L$ & $E$ & $R$ & $Y$ \\
\hline
\end{tabular}

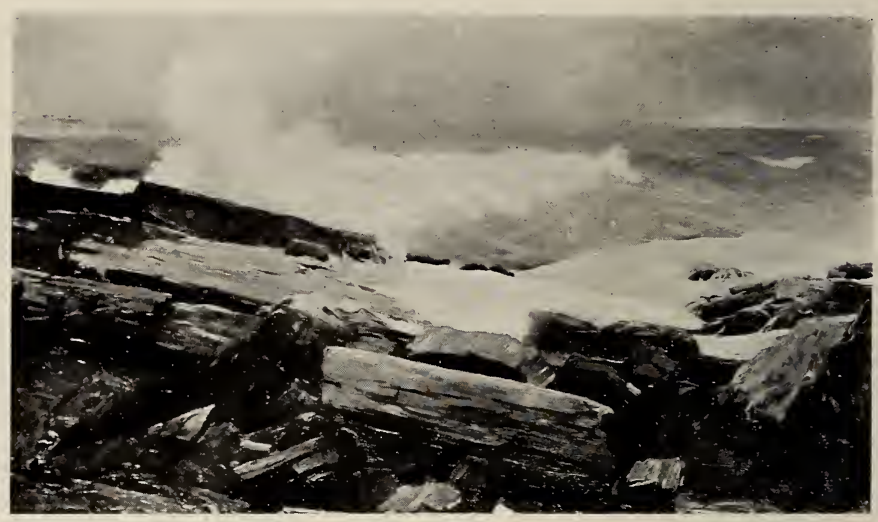

WEATHER BEATEN

-Privately Owned 


$\begin{array}{llllllllllllllllll}T & H & E & M & A & C & B & E & T & H & G & A & L & L & E & R & Y\end{array}$

\section{WINSLOW HOMER}

\section{$1836-1910$}

Born, Boston, Massachusetts, 1836. Died, Scarborough, Maine, 1910. Studied for a brief time at the National Academy of Design and with Frederic Rondel, but mainly self-taught. Member of the National Academy of Design, New York; American Water Color Society, New York; National Institute of Arts and Letters; American Academy of Arts and Letters.

Represented in the Metropolitan Museum, New York; Museum of Fine Arts, Boston; Art Institute of Chicago; Rhode Island School of Design, Providence, Rhode Island; Layton Art Gallery, Milwaukee, Wisconsin; Pennsylvania Academy of the Fine Arts, Philadelphia; Corcoran Art Gallery, Washington, D. C.; National Gallery of Art, Washington, D. C.; Carnegie Institute, Pittsburgh; Worcester Museum of Art, Massachusetts; Cincinnati Museum Association.

Awarded Gold Medal, World's Columbian Exposition, Chicago, 1893; First Prize, Carnegie Institute, Pittsburgh, 1896; Gold Medal, Pennsylvania Academy of the Fine Arts, Philadelphia, 1896; Gold Medal, Exposition Universelle, Paris, 1900; Gold Medal, Pan-American Exposition, Buffalo, 1901; Temple Gold Medal, Pennsylvania Academy of the Fine Arts, Philadelphia, 1902; Gold Medal, Charleston Exposition, 1902; Gold Medal, Universal Exposition, St. Louis, 1904. 


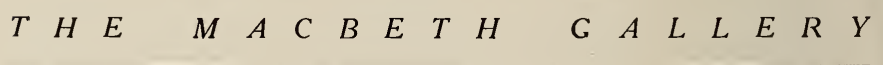

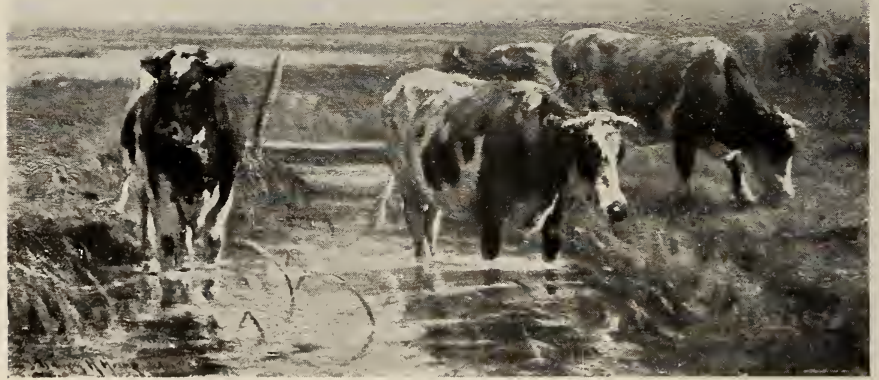

CLOUDY DAY 


\section{WILLIAM H. HOWE, N. A.}

Bronxville, N. Y. Born, Ravenna, Ohio, 1844. Pupil of Otto de Thoren and Vuillefroy, Paris. Member of Society of American Artists, 1899; National Institute of Arts and Letters; Artists' Fund Society; Lotos Club; Salmagundi Club. Elected Associate, National Academy of Design, 1894; Academician, 1897.

Represented in City Art Museum, St. Louis, Mo.; Cleveland Museum; Carnegie Institute, Pittsburgh, Pa.; Detroit Museum of Fine Arts; Alpha Delta Phi Club, New York; New York Athletic Club; National Gallery, Washington, D. C.; Corcoran Gallery, Washington D. C.; The Chicago Club; Lotos Club, New York.

Awarded Gold Medal, Chicago Exposition, 1883; Grand Gold Medal, San Francisco, 1884; Gold Medal, Atlanta, 1885; Honorable Mention, New Orleans, 1885; Honorable Mention, Paris Salon, 1886; Gold Medal, Paris Salon, 1888, and London, 1890; Temple Gold Medal, Pennsylvania Academy of the Fine Arts, 1890; Gold Medal, Boston, 1890; Silver Medal, Paris Exposition, 1889; Diploma, Hors Concours, Paris Salon, 1890; Palm of the Academy, Paris, 1895; Legion of Honor, 1898; Silver Medal, Buffalo, 1901; Special Gold Medal, St. Louis Exposition, 1904; Member of Jury, St. Louis Exposition, 1904. 


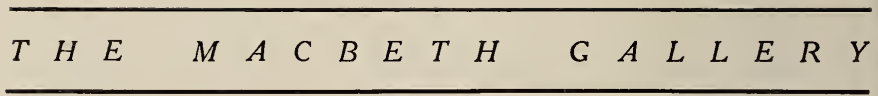

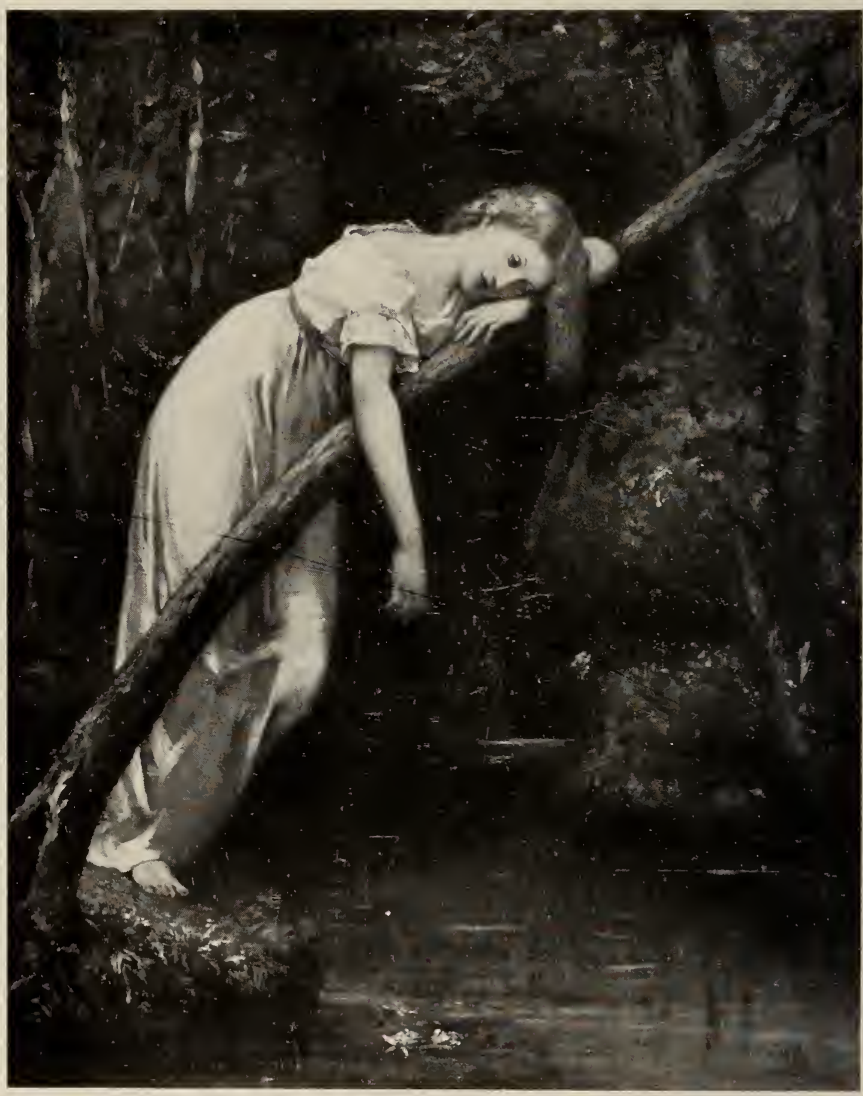

OPHELIA

-Privately Owned 


\section{$\begin{array}{llllllllllllllllll}T & H & E & M & A & C & B & E & T & H & G & A & L & L & E & R & Y\end{array}$}

\section{WILLIAM MORRIS HUNT}

\section{$1824-1879$}

Born Brattleboro, Vermont, March 31, 1824; died Weatherfield, Vermont, 1879. Entered the Dusseldorf Academy in 1846 to study sculpture, but gave this up shortly afterwards when he saw some paintings by Couture which decided him to be a painter instead. Studied under Couture in Paris, and later went to Holland to study and copy the old masters, especially Rembrandt. After his return to America lived in Newport, R. I., and Brattleboro, Vt. In 1862 opened a studio in Boston where he painted many portraits and figure compositions. Best known portrait that of Chief Justice Shaw, now in Court House of Salem, Mass. Went to Florida for his health about 1872 and there took up landscape painting for the first time. In 1875 went to Mexico, and some fine landscapes and figures resulted from this trip. In 1878 he visited Niagara and painted his famous picture of the Falls, which sold for ten thousand dollars a short time after his death. In the same year received commission for two large mural paintings setting forth the story of Columbus, to decorate the Capitol at Albany.

Represented in Metropolitan Museum of Art, New York; Boston Art Museum; City Art Museum, St. Louis, Mo., and in private collections of Dr. A. C. Humphreys, Mr. F. S. Smithers, Mr. Ralph T. King, Cleveland, Ohio, and others. 


\begin{tabular}{llllllllllllllllll}
$T$ & $H$ & $E$ & $M$ & $A$ & $C$ & $B$ & $E$ & $T$ & $H$ & & $G$ & $A$ & $L$ & $L$ & $E$ & $R$ & $Y$ \\
\hline
\end{tabular}

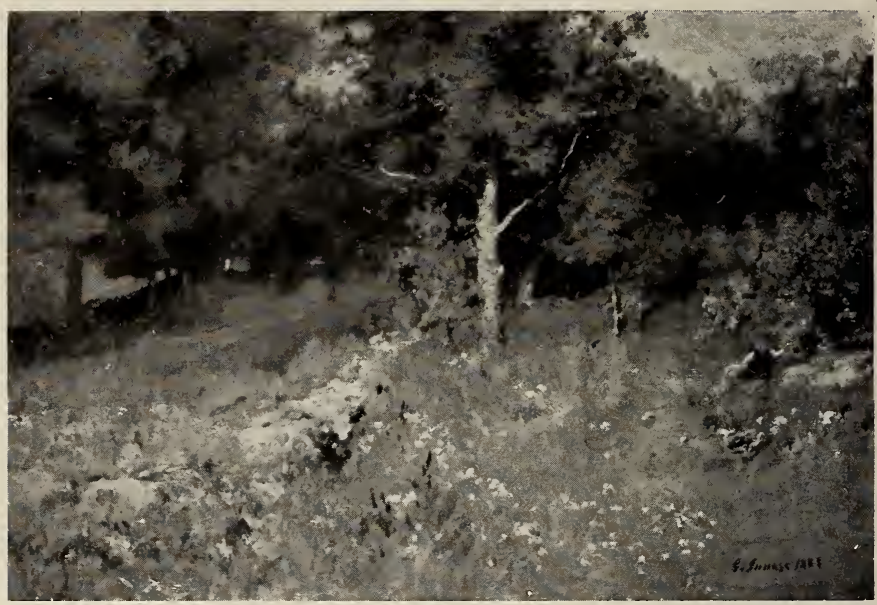

SUMMER FOLIAGE 


\section{GEORGE INNESS}

\section{5-1894}

Born, Newburgh, New York, May 1, 1825. Died, Scotland, 1894. Studied engraving in New York, and later painting under Regis Gignoux, a French artist of note who was staying in New York at that time. Spent the years 1847-48 studying and painting in Rome. Travelled and painted in France and Italy from 1871 to 1875 . Elected Associate of National Academy 1853, Academician, 1868. Best work painted in New Jersey in the vicinity of Montclair, where he lived.

Represented in Metropolitan Museum of Art, New York City; Brooklyn Institute of Arts and Sciences; Art Museum, Worcester, Mass.; Art Institute of Chicago; Corcoran Art Gallery, Washington, D. C.; National Gallery, Washington, D. C.; City Art Museum, St. Louis, Mo.; New York Public Library; Wilstach Collection, Memorial Hall, Philadelphia, Pa. 


\section{$\begin{array}{lllllllllllllllllll}T & H & E & & M & A & C & B & E & T & H & G & A & L & L & E & R & Y\end{array}$}

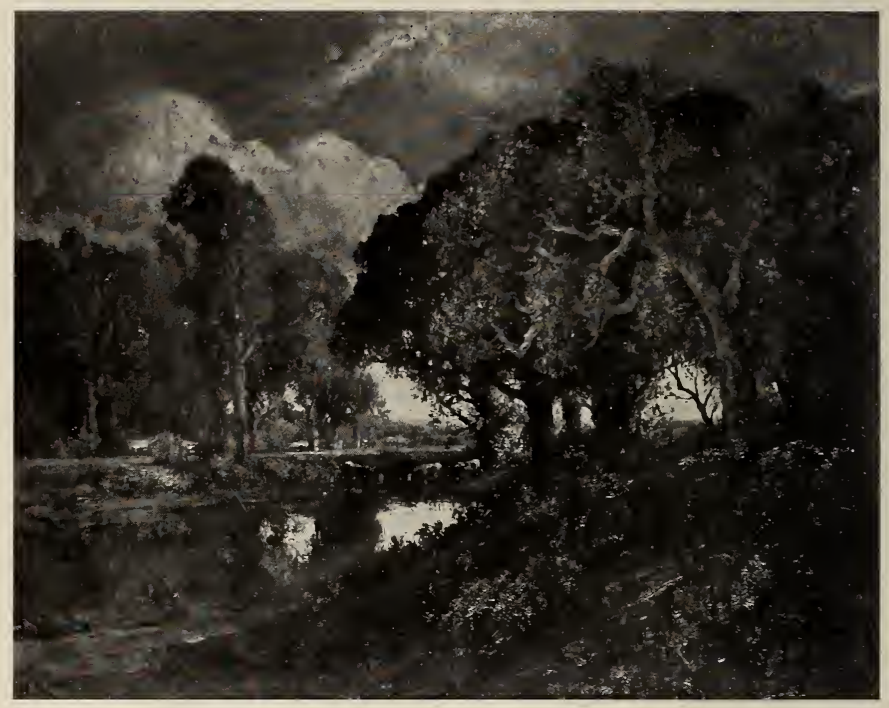

BY THE CREEK, SONOMA

-Corcoran Gallery, Washington 


\section{WILLIAM KEITH}

\section{$1839-1911$}

Born, Old Meldrum, Aberdeenshire, Scotland, November, 1839. His early boyhood was spent on the family estate near Cowie, but he removed to New York when about twelve years old. Secured a position in a lawyer's office, studying wood engraving in spare time. Deciding to devote his whole time to art, he joined the staff of Harper's Weekly and Harper's Monthly, remaining with them until 1859, when he moved to California. In 1869 he went abroad, seeing the foreign masters and studying in Dusseldorf. Returned to California and established studio in San Francisco. Lost almost all his effects in the San Francisco fire in 1906. Continued to paint in San Francisco until his death, at his home in Berkeley, in 1911.

Represented in San Francisco Institute of Art; Corcoran Gallery, Washington, D. C.; Art Institute of Chicago; Blanchard Gallery, Los Angeles; Brooklyn Institute of Arts and Sciences; Frankfurt Gallery, Germany.

Awarded Cold Medal, Mechanics' Institute, Boston, Mass., 1869; Bronze Medal, Pan-American Exposition, Buffalo, N. Y., 1901. 


\section{$\begin{array}{lllllllllllllllll}T & H & E & & M & A & C & B & E & T & H & G & A & L & L & E & R\end{array}$}

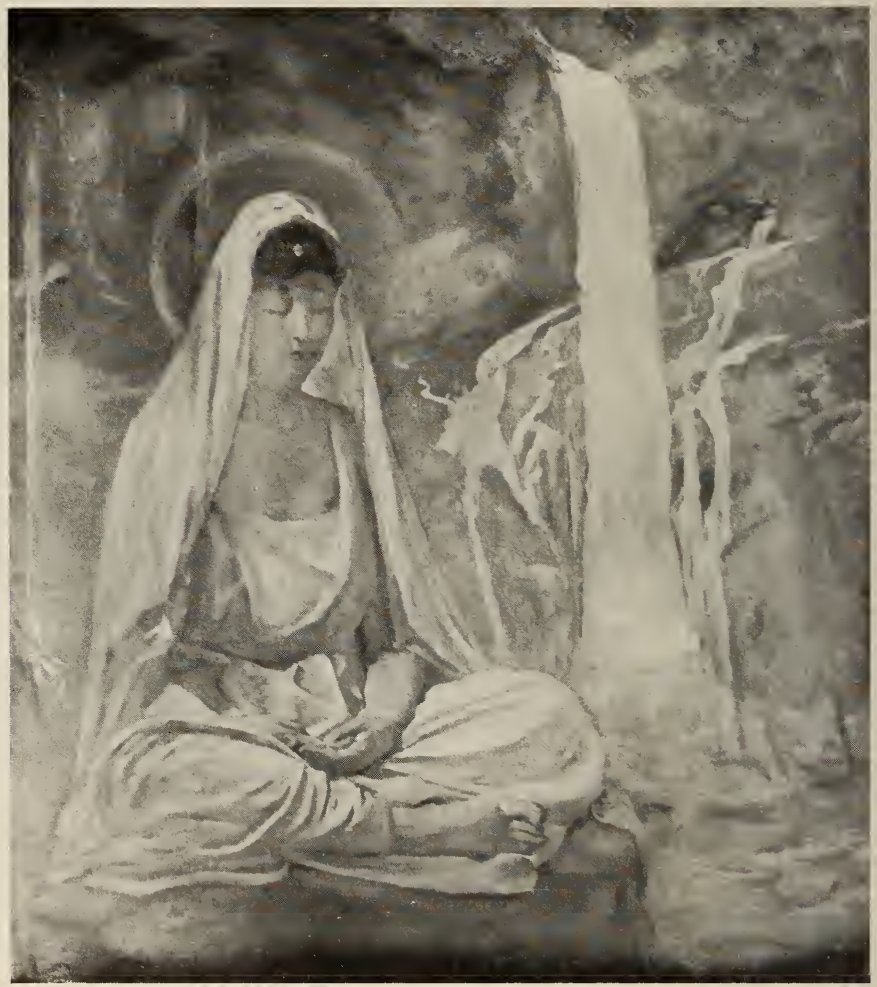

KWAUNON MEDITATING ON HUMAN LIFE 


\section{JOHN LA FARGE}

\section{$1835-1910$}

Born, New York City, March, 1835. Died, Providence, R. I., Nov. 14, 1910. When six years old, his grandfather, who was a miniature painter, gave him his first lessons in art. After receiving a classic and legal education, he went abroad to study art, and there came under the influence of Couture. Spent most of his time studying the old masters in the various museums. Returned to America to take up law, but abandoned it to study painting under William Morris Hunt. At first he painted landscapes, figures and still life, and later took up decorative work. In 1876 received commission to decorate interior of Trinity Church, Boston. Work of a similar kind followed this, including decoration in St. Thomas's, New York, 1877, Church of the Incarnation, New York, 1885, Church of the Ascension, New York, 1885 , and elsewhere. Designed stained glass windows for many churches and private homes, and was widely known for this kind of decoration. Traveled extensively in Japan and the South Sea Islands, and his work of this period is very imaginative and full of beauty. Was well known as writer and lecturer on art.

Represented in Metropolitan Museum, New York; City Art Museum, St. Louis; Museum of Art, Worcester, Mass.; Walters Collection, Baltimore; besides many churches, public buildings, and private collections.

Awarded Legion of Honor, 1889; Gold Medal, Pan-American Exposition, Buffalo, 1901; Diploma and Medal of Honor, St. Louis, 1904; Architectural League of New York Medal of Honor, 1909; Elected Associate, National Academy of Design, 1863; Academician, 1869. 


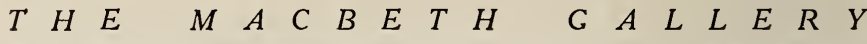

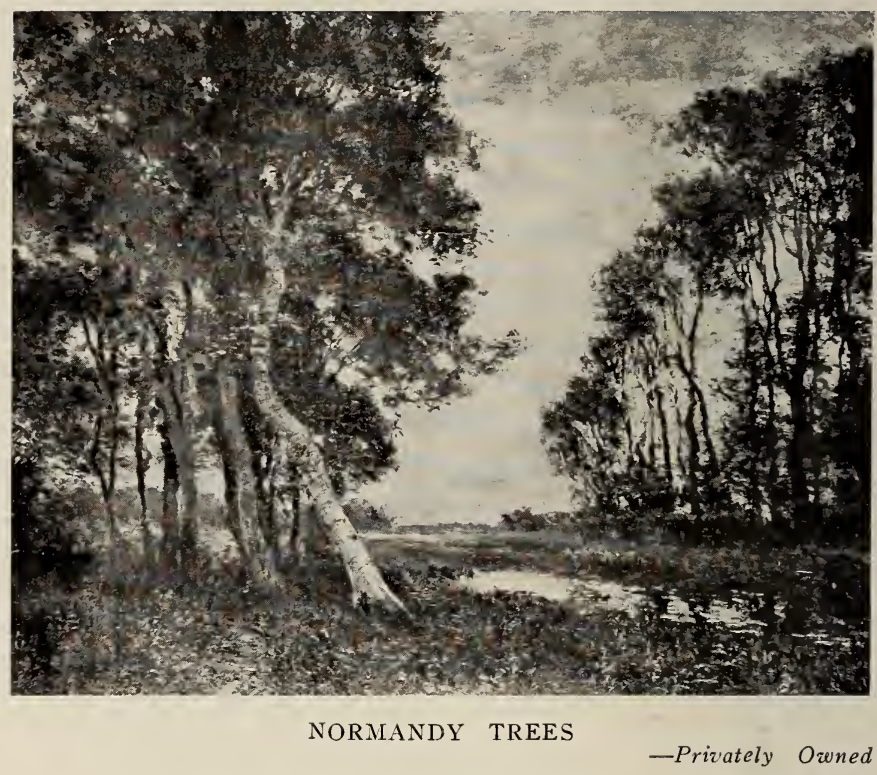




\section{HOMER D. MARTIN}

\section{6-1897}

Born, Albany, New York, October 28, 1836. Died St. Paul, Minn., February 12, 1897. Selftaught, except for a short period when he received instruction from William Hart. Made frequent trips to the Adirondacks and White Mountains, and recorded his observations by numerous pencil sketches that still exist. First exhibited at the $\mathrm{Na}$ tional Academy of Design, New York, in 1857. In 1862 came to New York and worked in the studio of James Smillie, and in 1865 rented attic studio in the old Tenth Street building which he kept for sixteen years. In 1876 went to England and France, and studied the old masters whose pictures influenced his color. In 1861 was sent to England by the Century Magazine to sketch "George Elliott's Country". Spent the period 1882-1886, known as his "Villerville-Honfleur period", in Normandy where some of his finest pictures were painted, notably "Harp of the Winds" (Metropolitan Museum), "Sun Worshippers" (Mr. Louis Marshall), "On the Seine" (Mr. Walter Jennings), "Honfleur Light" (Century Association). Was almost totally blind for about five years before his death. Elected member Century Association, 1866; Associate, National Academy, 1868; Academician, 1875; Member Society American Artists 1877.

Represented in Metropolitan Museum, New York; Art Institute of Chicago; Art Museum, Worcester, Mass.; Brooklyn Institute; National Gallery, Washington, D. C. 


\section{$\begin{array}{lllllllllllllllllll}T & H & E & & M & A & C & B & E & T & H & G & A & L & L & E & R & Y\end{array}$}

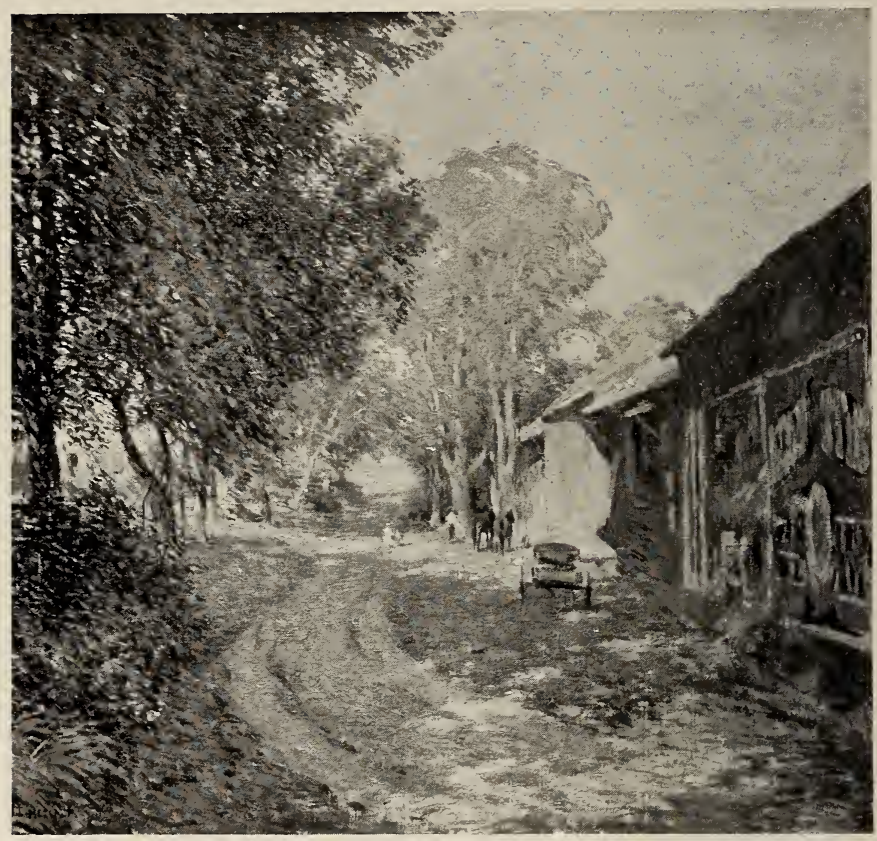

MIDSUMMER 


\section{WILLARD L. METCALF}

New York City. Born, Lowell, Massachusetts, 1858. Studied with Boulanger and Lefebvre in Paris. Member of Ten American Painters; American Water Color Society and National Institute of Arts and Letters, New York; Union Internationale des Beaux Arts et des Lettres, Paris.

Represented in the National Gallery, Washington, D. C.; Corcoran Gallery of Art, Washington, D. C.; Museum of Fine Arts, Boston; Art Institute of Chicago; Pennsylvania Academy of the Fine Arts, Philadelphia; Cincinnati Art Museum; Art Museum, Rochester, N. Y.; Worcester Art Museum; Hillyer Art Gallery, Smith College, Northampton, Massachusetts; St. Botolph Club, Boston; Detroit Museum of Art; Hackley Art Museum, Muskegon, Michigan.

Honorable Mention, Salon, Paris, 1888; Bronze Medal, Columbian Exposition, Chicago, 1893; Webb Prize, Society of American Artists, New York, 1896; Honorable Mention, Exposition Universelle, Paris, 1900; Silver Medal, Pan-American Exposition, Buffalo, 1901; Silver Medal, Universal Exposition, St. Louis, 1904; Temple Gold Medal, Pennsylvania Academy of the Fine Arts, 1907; First William A. Clark Prize and Corcoran Gold Medal, Corcoran Gallery of Art, 1907; Harris Silver Medal, Art Institute of Chicago, 1910; Gold Medal, International Fine Arts Exposition, Buenos Aires, 1910; Gold Medal of Honor, Pennsylvania Academy of the Fine Arts, 1911; Sesnan Gold Medal, Pennsylvania Academy of the Fine Arts, 1912. 


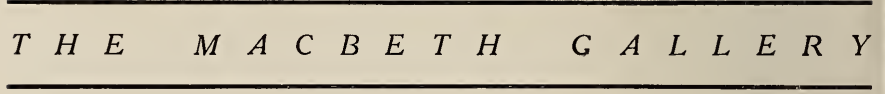

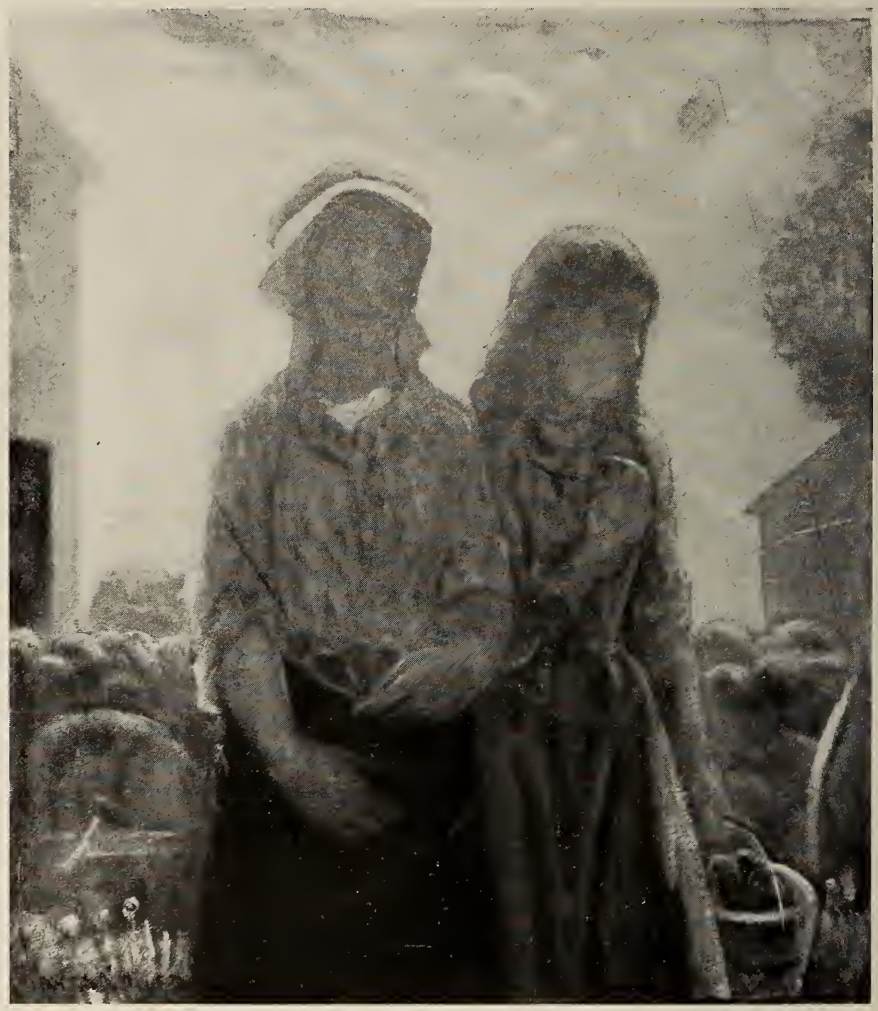

THE FARMYARD 
$\begin{array}{llllllllllllllllll}T & H & E & M & A & C & B & E & T & H & G & A & L & L & E & R & Y\end{array}$

\section{KENNETH HAYES MILLER}

New York City. Born, Kenwood, New York, March 11, 1876. Pupil of Art Students' League and Chase School. Instructor of Drawing and Painting at Art Students' League of New York.

Member Union Internationale des Beaux Arts, Paris. 


\section{$\begin{array}{llllllllllllllllll}T & H & E & & M & A & C & B & E & T & H & G & A & L & L & E & R & Y\end{array}$}

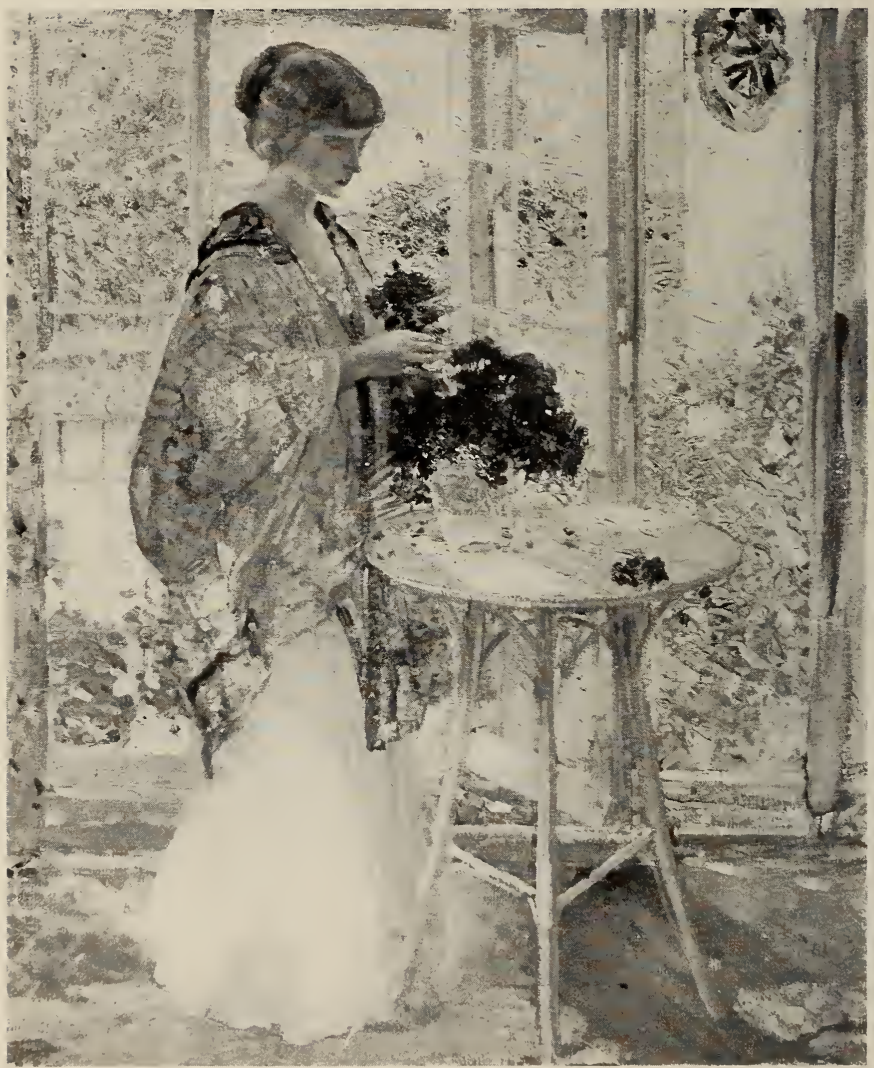

MORNING SUNLIGHT 


\section{RICHARD E. MILLER, A. N. A.}

Paris, France. Born, St. Louis, Missouri. Member of the Paris Society of American Painters, National Association of Portrait Painters, New York.

Represented in the Luxembourg, Paris; Palais des Beaux-Arts de la Ville de Paris; Museum of Fine Arts, Antwerp; International Gallery of Modern Art, Venice; Metropolitan Museum; Art Institute, Kansas City, Mo.; Albright Art Gallery, Buffalo, N. Y.; City Art Museum, St. Louis, Mo.

Awarded Medal of the Second Class, Salon, Paris, 1904; Temple Gold Medal, Pennsylvania Academy of the Fine Arts, Philadelphia, 1911; Knight of the Legion of Honor, France. 


\section{$\begin{array}{llllllllllllllllll}T & H & E & & M & A & C & B & E & T & H & G & G & A & L & L & E & R\end{array}$}

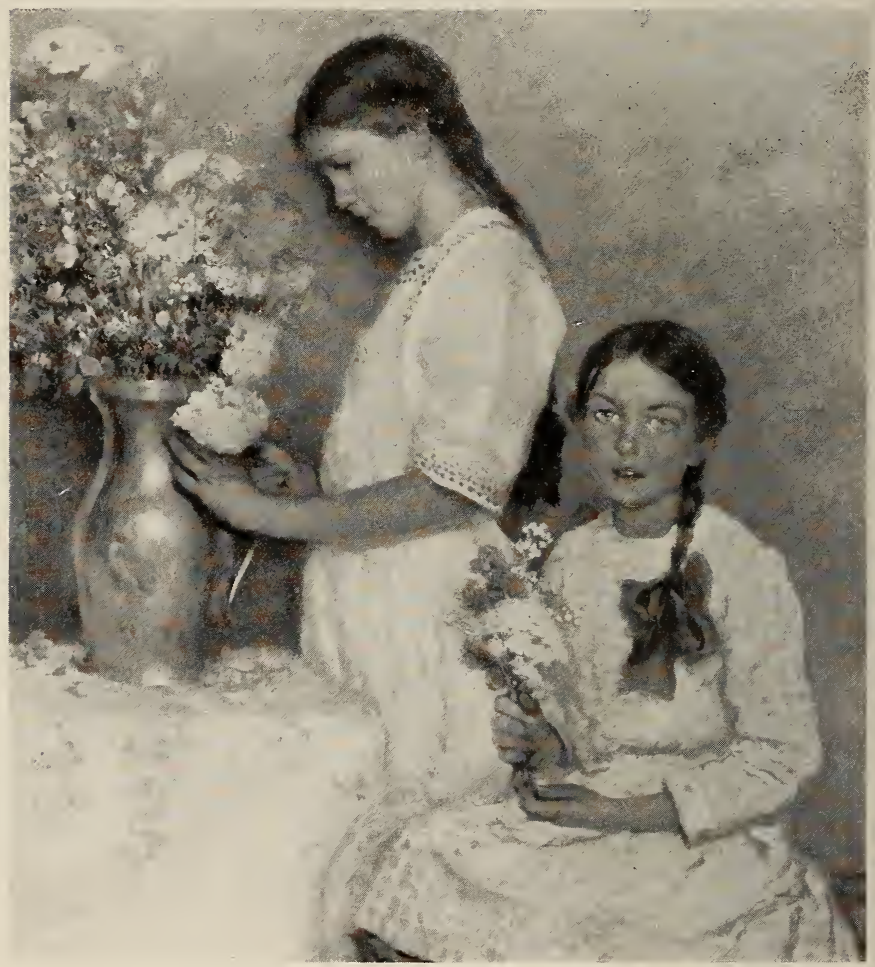

FLOWERS OF THE FIELD 


\section{F. LUIS MORA, N. A.}

New York City. Born, Montevideo, Uruguay July 27, 1874. Pupil of his father and Benson and Tarbell, Boston Art School; Art Students' League, under Mowbray. Member of the National Academy of Design, National Arts Club, Lotos Club, Salmagundi Club, Architectural League of New York, New York Water Color Society, and of the Society of Illustrators, New York.

Represented in the Boston Art Club; Columbia University, New York; Public Library, Lynn, Massachusetts; Art Association, Lafayette, Indiana; Art Gallery, Oakland, California; Dallas Art Association, Dallas, Texas; Art Association of Muncie, Indiana.

Awarded Gold Medal, Art Club of Philadelphia, 1901; Bronze Medal, Universal Exposition, St. Louis, 1904; First Hallgarten Prize, National Academy of Design, 1905; Beal Prize, New York Water Color Club, 1907; Silver Medal, International Exposition, Buenos Aires, 1910; Evans Prize, Salmagundi Club; Shaw Purchase Prize, Salmagundi Club. 


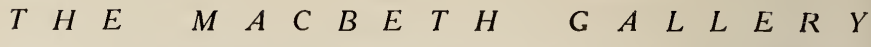

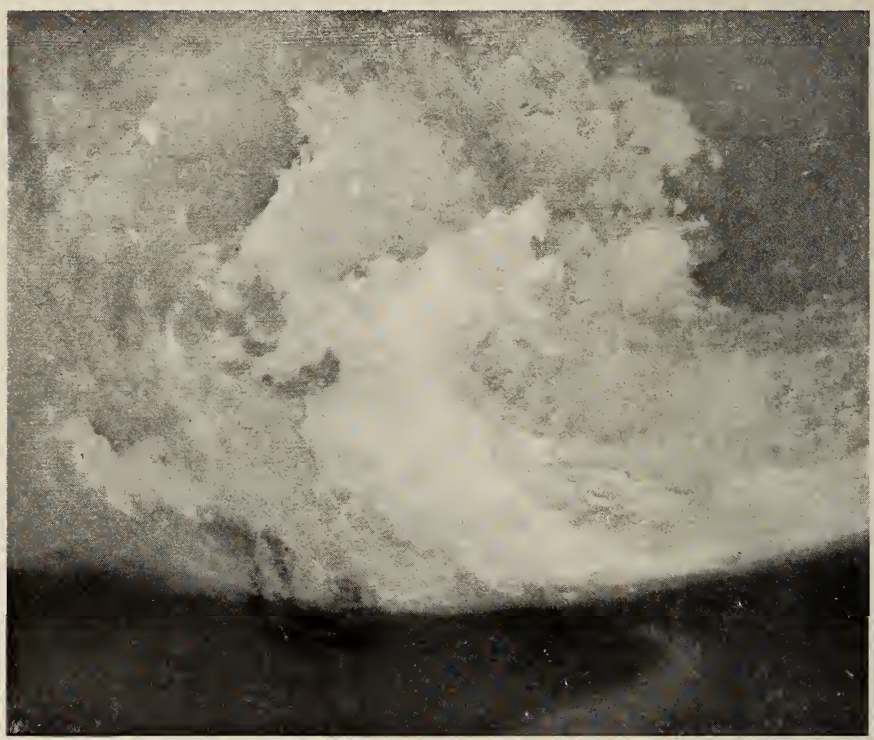

THE STORM 


\section{HERMANN DUDLEY MURPHY}

Winchester, Mass. Born, Marlboro, Mass., Aug. 25, 1867. Pupil of Boston Museum School; Laurens in Paris. Member, Copley Society, 1886; St. Botolph Club; Boston Water Color Club; New York Water Color Club; Salmagundi Club; National Arts Club; Boston Society of Arts and Crafts.

Represented in Art Institute of Chicago; Art Association, Nashville, Tenn.; Albright Art Gallery, Buffalo.

Awarded Bronze Medal, Pan-American Exposition, Buffalo, 1901; Silver Medal for Portrait and Bronze Medal for Water Color, St. Louis Exposition, 1904. 


\begin{tabular}{llllllllllllllllll}
\hline$T$ & $H$ & $E$ & $M$ & $A$ & $C$ & $B$ & $E$ & $T$ & $H$ & & $G$ & $A$ & $L$ & $L$ & $E$ & $R$ & $Y$ \\
\hline
\end{tabular}

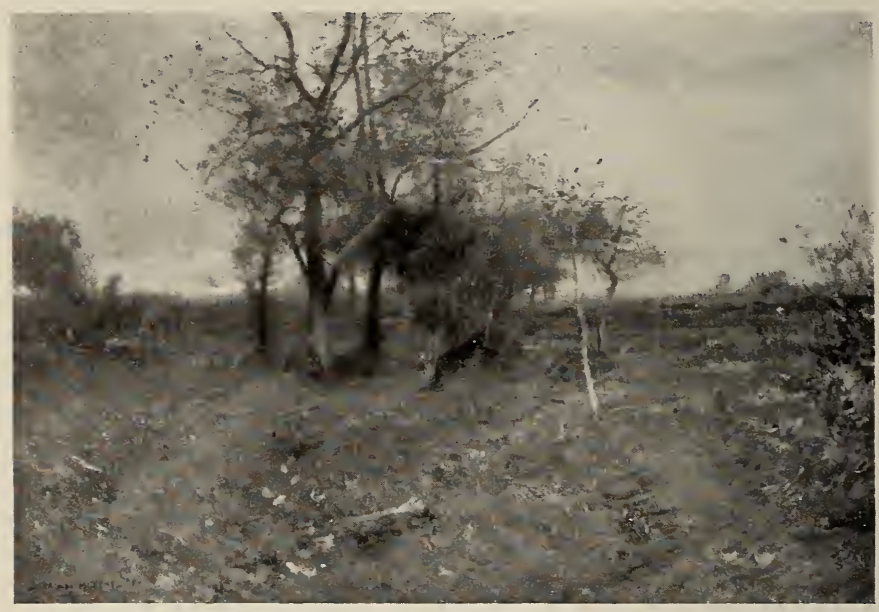

EVENING-NOVEMBER GRAYS 


\section{J. FRANCIS MURPHY, N. A.}

New York City. Born, Oswego, N. Y., Dec. 11, 1853. Member of the National Academy of Design, and of the American Water Color Society, New York.

Represented in the Metropolitan Museum of Art, New York; Corcoran Gallery of Art, Washington, D. C.; Art Institute of Chicago; Worcester Art Museum; Art Institute, Kansas City, Mo.; National Gallery of Art, Washington, D. C.; Albright Art Gallery, Buffalo; Carnegie Institute, Pittsburgh; Museum of Art, Detroit, Mich.

Awarded Second Hallgarten Prize, National Academy of Design, 1885; Webb Prize, Society of American Artists, New York, 1887; Gold Medal, American Art Association, 1887; Medal, Columbian Exposition, Chicago, 1893; William T. Evans Prize, American Water Color Society, New York, 1894; Gold Medal, Philadelphia Art Club, 1899; Honorable Mention, Exposition Universelle, Paris, 1900; Silver Medal, Pan-American Exposition, Buffalo, 1901; Gold Medal, Charleston Exposition, 1902; Carnegie Prize, Society of American Artists, 1902; Silver Medal, Universal Exposition, St. Louis, 1904; Inness Gold Medal, National Academy of Design, 1910; Gold Medal, International Exposition, Buenos Aires, 1910. 


\section{$\begin{array}{llllllllllllllllll}T & H & E & & M & A & C & B & E & T & H & G & A & L & L & E & R & Y\end{array}$}

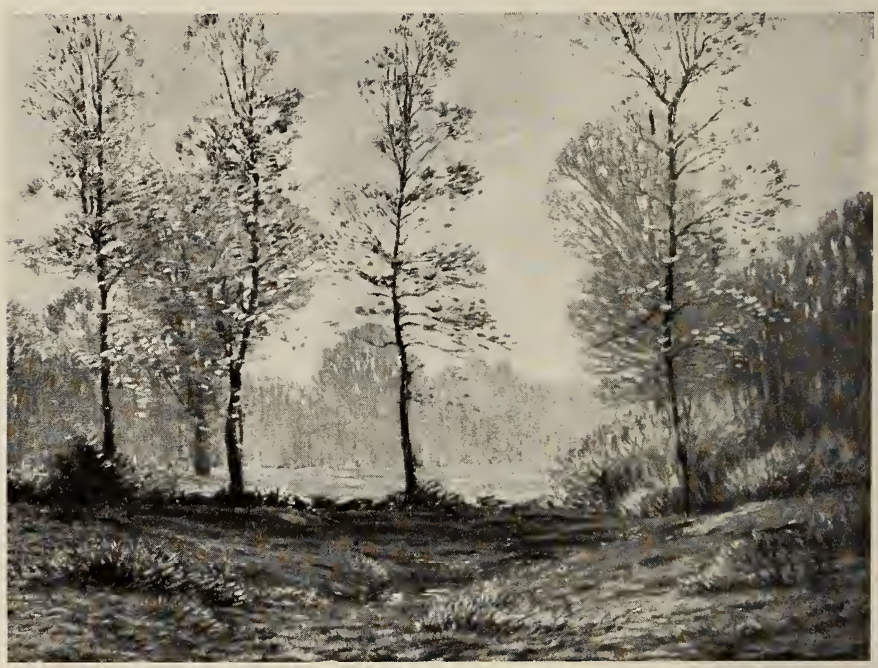

JUNE MORNING 


\section{LEONARD OCHTMAN, N. A.}

New York and Cos Cob, Conn. Born, Holland, Oct. 21, 1854. Settled at Albany, N. Y., 1866. Self-taught. Elected Associate, National Academy of Design, 1898; Academician, 1904. Member of Society of American Artists, 1891; American Water Color Society; New York Water Color Club; Brooklyn Art Club; Artists' Fund Society; Artists' Aid Society; Salmagundi Club; Lotos Club; National Institute of Arts and Letters.

Represented in Metropolitan Museum, New York; Corcoran Gallery, Washington, D. C.; City Art Museum, St. Louis, Mo.; National Gallery, Washington, D. C.; Institute of Arts and Sciences, Brooklyn, N. Y.; Gallery of Fine Arts, Columbus, O.; Art Museum, Denver, Col.; Art Museum, Richmond, Ind.; Hackley Art Gallery, Muskegon, Mich.; Art Gallery, Fort Worth, Texas; Art Association, Dallas, Texas.

Awarded Prize, Brooklyn Art Club, 1891; Medal, Columbian Exposition, Chicago, 1893; Gold Medal, Art Club of Philadelphia, 1894; Silver Medal, Pan-American Exposition, Buffalo, 1901; Silver Medal, Charleston, 1902; Morgan Prize, Salmagundi Club, 1902; Shaw Fund Prize, Society of American Artists, 1902; Inness Gold Medal, National Academy of Design, 1903; Evans Prize, Salmagundi Club, 1903; Webb Prize, Society of American Artists, 1904; Gold Medals for Oil and Water Color, St. Louis Exposition, 1904; Second Prize, Society Washington Artists, 1905; Read Purchase, Richmond (Ind.) Art Club, 1905; Inness Prize, Salmagundi Club, 1907; Medal of the Second Class, Knoxville Exposition, 1911. 


$\begin{array}{llllllllllllllllll}T & H & E & M & A & C & B & E & T & H & G & G & L & L & E & R & Y\end{array}$

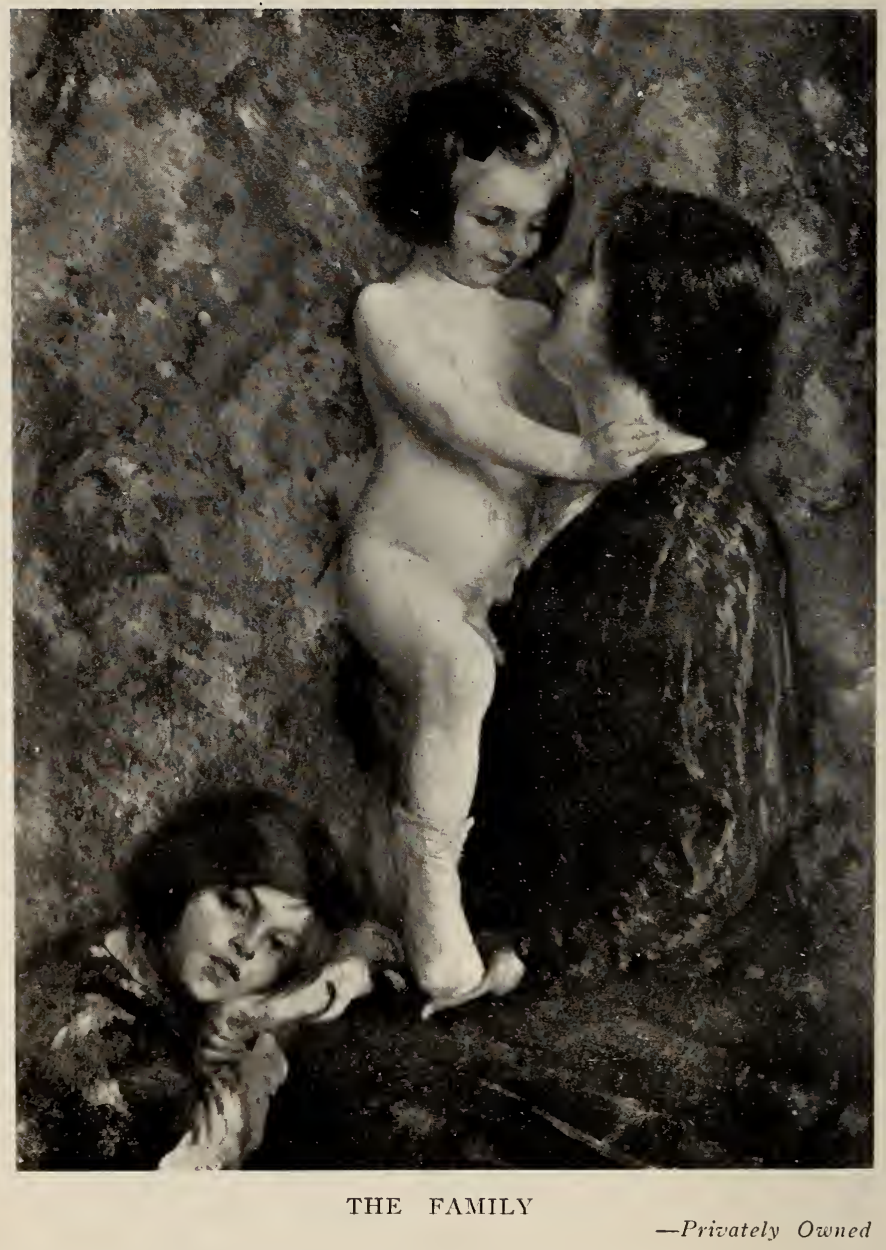




\section{$\begin{array}{llllllllllllllllll}T & H & E & & M & A & C & B & E & T & H & G & A & L & L & E & R & Y\end{array}$}

\section{IVAN G. OLINSKY, A. N. A.}

New York City. Born South Russia, 1878. Came to this country, 1891. Pupil of National Academy of Design, 1893-1898, winning all school prizes. For eight years assistant to John La Farge. Studied abroad, 1908, in Venice and Paris, exhibiting at Salon. Returned to America in 1911. On Faculty of Schools of National Academy of Design. Member Association of Mural Painters; Salmagundi Club. Elected Associate of National Academy of Design, 1914.

Awarded Thomas B. Clarke Prize, National Academy of Design, 1914. 


\begin{tabular}{llllllllllllllllll}
$T$ & $H$ & $E$ & $M$ & $A$ & $C$ & $B$ & $E$ & $T$ & $H$ & $G$ & $A$ & $L$ & $L$ & $E$ & $R$ & $Y$ \\
\hline
\end{tabular}

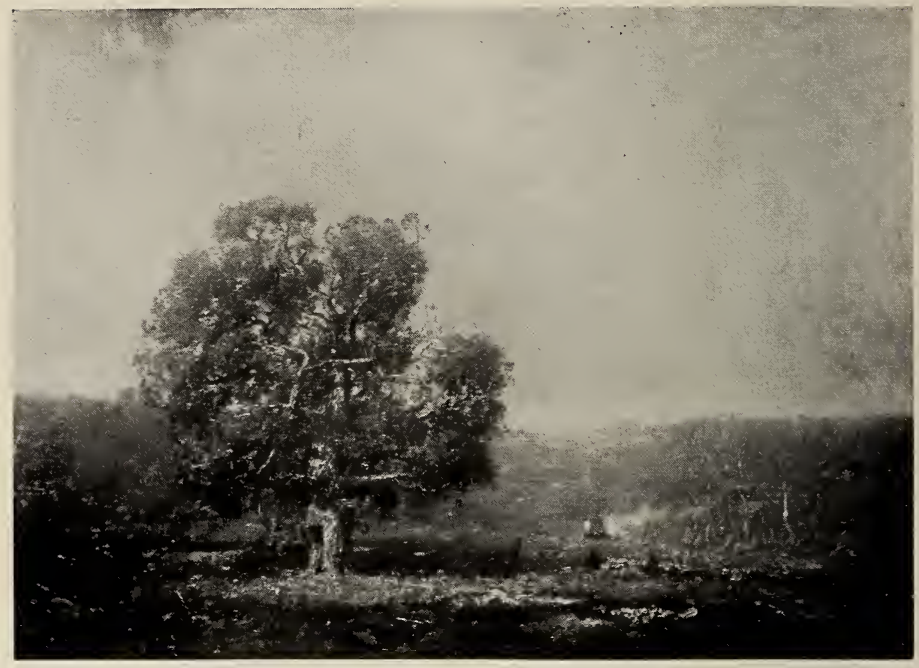

AN OLD VETERAN 


\section{HENRY W. RANGER, N. A.}

New York City; Born, Western New York, 1858. Studied art outside of academies and during several years' residence in France, England and Holland. Member of the National Academy of Design, Lotos Club, and of the American Water Color Society.

Represented in the Corcoran Gallery, Washington, D. C.; Metropolitan Museum, New York; Carnegie Institute, Pittsburgh; and in the collections of the Lotos Club, New York; William T. Evans, John Harsen Rhoades, Dr. Alexander C. Humphreys, and many others in America and Europe.

Awarded Bronze Medal, Exposition Universelle, Paris, 1900; Silver Medal, Pan-American Exposition, Buffalo, 1901; Gold Medal, Charleston Exposition, 1902. 


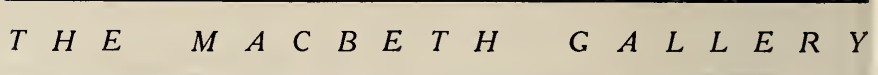

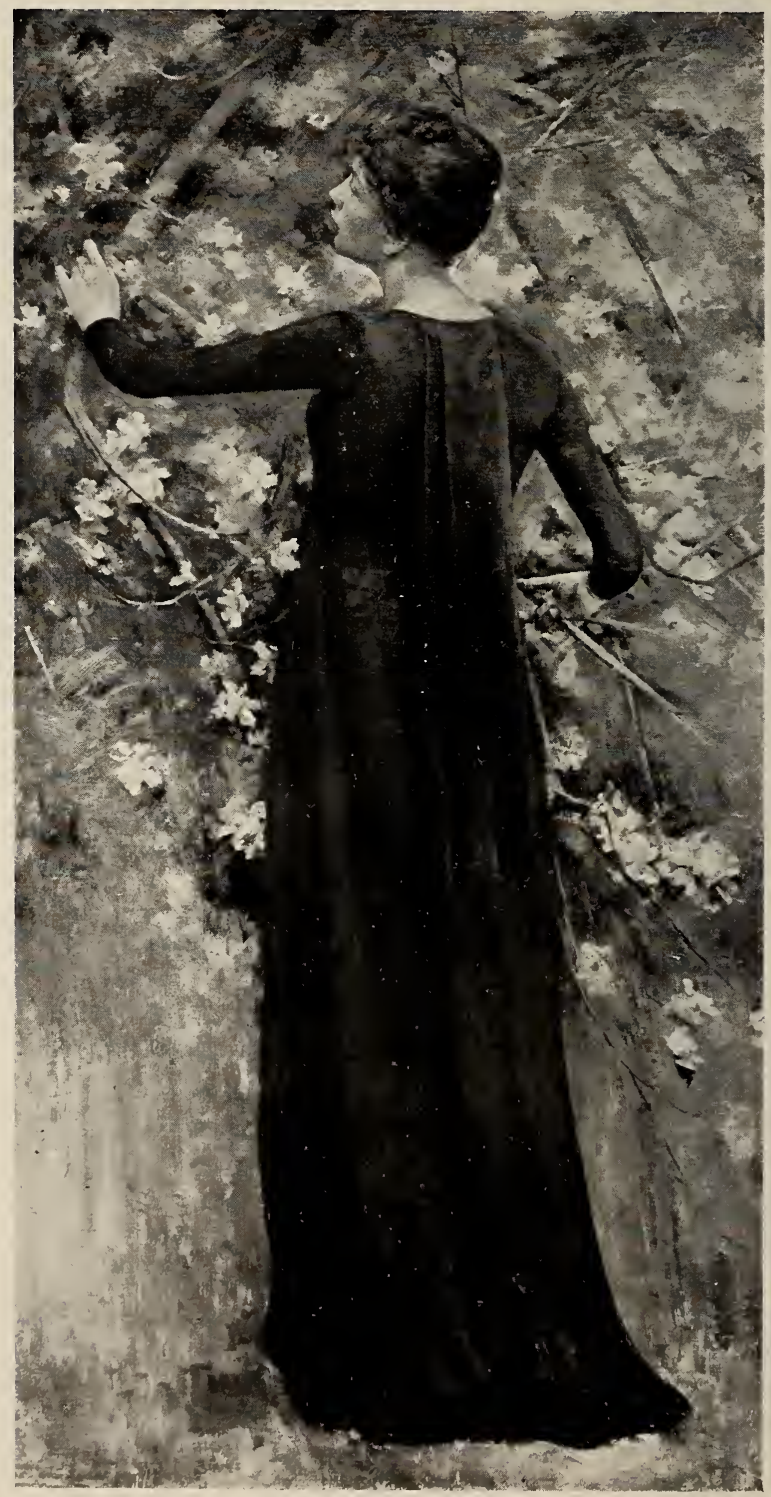




$\begin{array}{llllllllllllllllll}T & H & E & & M & A & C & B & E & T & H & G & A & L & L & E & R & Y\end{array}$

\section{THEODORE ROBINSON}

$1852-1896$

Born, Irasburg, Vermont, 1852; died, New York, April 2, 1896. Pupil of Carolus-Duran and Gérôme in Paris, from 1874 to 1879 . Had a studio in New York from about 1880 to 1884 , when he returned to France and spent several years at Giverny, where he worked under the influence of Claude Monet. When he finally returned to America, he painted along the Delaware and Hudson Canal, for the most part figures in-doors and out-of-doors, in the impressionistic manner he had acquired abroad. He was a member of the Society of American Artists, where he was a regular contributor to exhibitions.

Represented in the Metropolitan Museum, New York; the Carnegie Institute, Pittsburgh; as well as in other museums and private collections.

Awarded Webb Prize, Society of American Artists, 1890; Shaw Fund Prize, Society of American Artists, 1892; Medal, Columbian Exposition, Chicago, 1893. 


\section{$\begin{array}{lllllllllllllllllll}T & H & E & & M & A & C & B & E & T & H & G & A & L & L & E & R & Y\end{array}$}

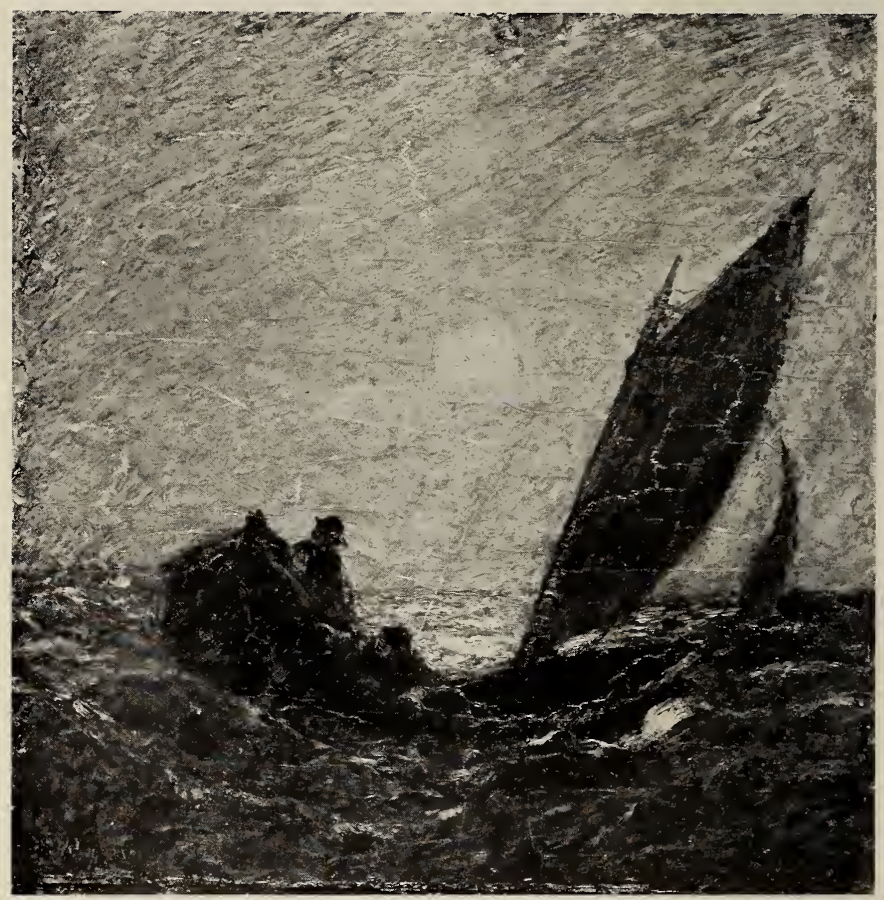

WITH SLOPING MAST AND DIPPING PROW

-Privately Owned 


\section{ALBERT P. RYDER, N. A.}

New York City. Born New Bedford, Mass., March 19, 1847. Pupil of William E. Marshall, engraver, and of the National Academy of Design. Studied abroad in 1877 and 1882. Elected Associate of National Academy of Design, 1902, Academician, 1906; Society of American Artists, 1878; National Academy of Arts and Letters.

Awarded Silver Medal, Pan-American Exposition, Buffalo, 1901.

Represented by "The Bridge," "The Curfew Hour" and "Smugglers" in Metropolitan Museum, New York; Institute of Arts and Sciences, Brooklyn, N. Y. 


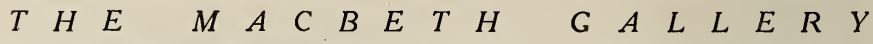

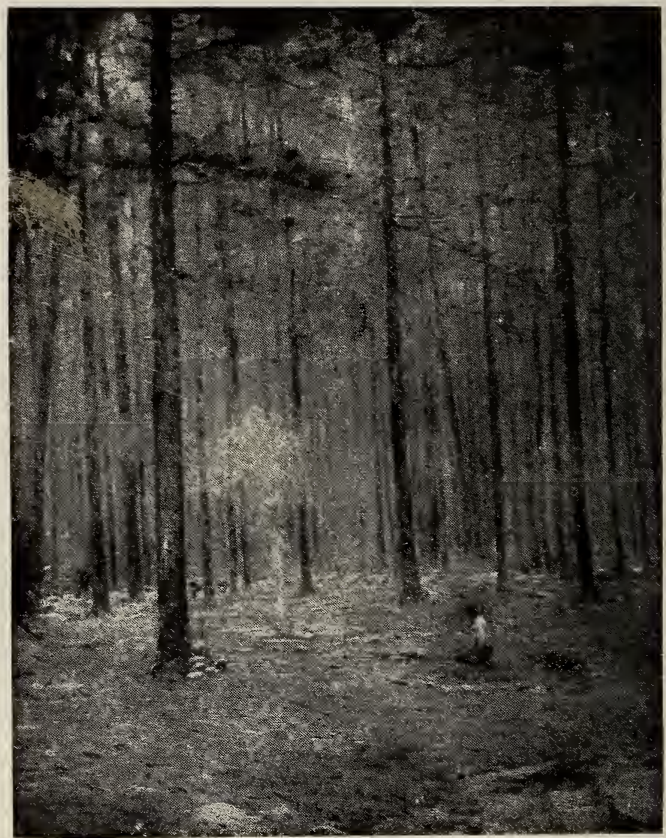

THE MAKER OF MAGIC

-Privately Owned 
CHAUNCEY F. RYDER, A. N. A.

New York City. Born Danbury, Connecticut, Feb. 28, 1868. Pupil of Chicago Art Institute; Julien Academy; Collin and Laurens, Paris. Elected Associate, National Academy of Design, 1913. Member of the American Water Color Society; Salmagundi Club, New York.

Represented in the Art Institute of Chicago; the Isaac Delgado Museum of Art, New Orleans; Washington State Art Association, Seattle; Corcoran Art Gallery, Washington, D. C.; Hackley Gallery, Muskegon, Michigan; Société des Amis des Arts, Douai, France; National Museum of Art, Toronto, Canada; Engineers' Club, New York. Awarded Honorable Mention, Salon, Paris, 1907. 


\begin{tabular}{lllllllllllllllllll}
\hline$T$ & $H$ & $E$ & $M$ & $A$ & $C$ & $B$ & $E$ & $T$ & $H^{\prime}$ & $G$ & $A$ & $L$ & $L$ & $E$ & $R$ & $Y$ \\
\hline
\end{tabular}

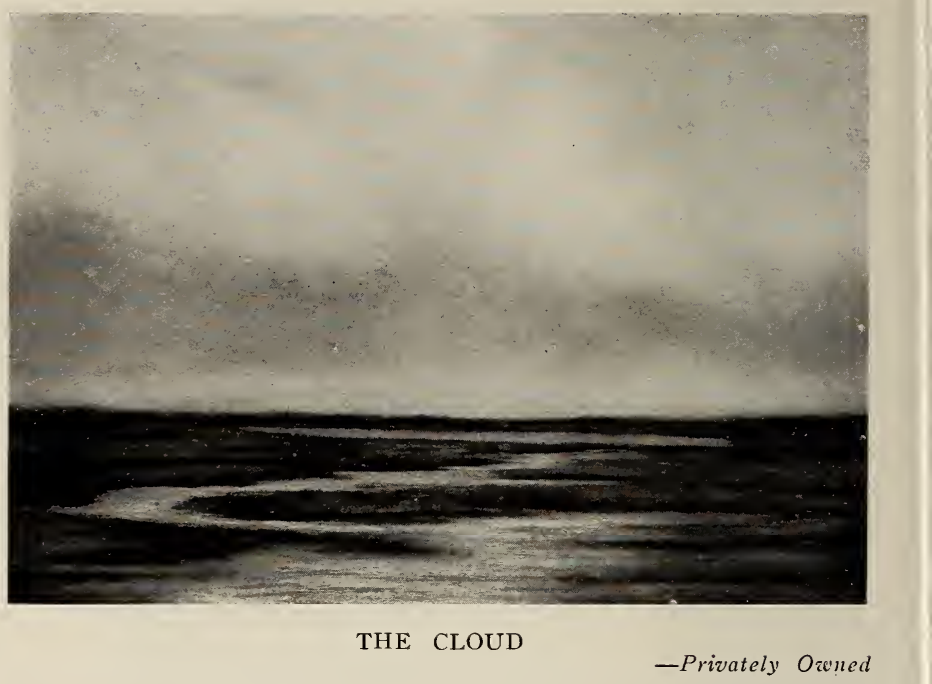




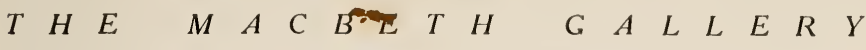

\section{WILLIAM SARTAIN, N. A.}

New York City. Born, Philadelphia, Pennsylvania, Nov. 21, 1843. Pupil of Pennsylvania Academy of the Fine Arts; Bonnat and Ecole des Beaux Arts, Paris; also studied in Italy and Spain. Member of the National Academy of Design, New York.

Represented in the Metropolitan Museum of Art, New York; Corcoran Gallery of Art, and National Gallery, Washington, D. C.

Awarded Silver Medal, Boston, 1881; Honorable Mention, Pennsylvania Academy of the Fine Arts, Philadelphia, 1887; Bronze Medal, PanAmerican Exposition, Buffalo, 1901; Silver Medal, Charleston Exposition, 1902; Silver Medal, International Exposition, Buenos Aires, 1910. 


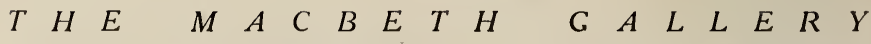

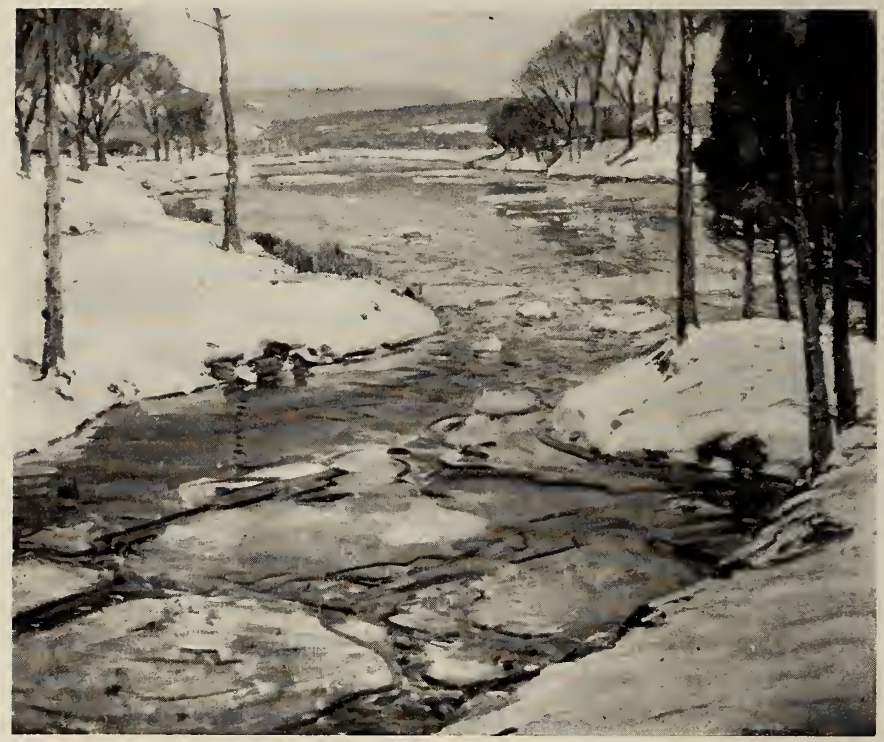

THE RIVER

-Minneapolis Museum of Art 


\section{GARDNER SYMONS, N. A.}

New York City. Born, Chicago, Illinois. Studied in Paris, Munich and London. Member of the National Academy of Design, and of the National Arts Club, New York; Society of Men Who Paint the Far West; Royal Society of British Artists, London; Union Internationale des Beaux-Arts et des Lettres, Paris.

Represented in the Metropolitan Museum of Art, New York; Corcoran Gallery of Art, Washington, D. C.; Art Institute of Chicago; National Arts Club, New York; Cincinnati Museum; Nebraska Art Association, Lincoln, Nebraska; Toledo Museum of Art; Art Museum, Minneapolis, Minn.; Brooklyn Institute of Arts and Sciences; Carnegie Institute, Pittsburgh, Pa.; Art Museum, Fort Worth, Texas.

Awarded Carnegie Prize, National Academy of Design, 1909; Bronze Medal, International Exposition, Buenos Aires, 1910; Gold Medal, National Arts Club, 1912; Third W. A. Clark Prize and Corcoran Bronze Medal, Corcoran Gallery of Art, 1912; Saltus Medal for Merit, National Academy of Design, 1913. 


\section{$\begin{array}{lllllllllllllllllll}T & H & E & & M & A & C & B & E & T & H & G & A & L & L & E & R & Y\end{array}$}

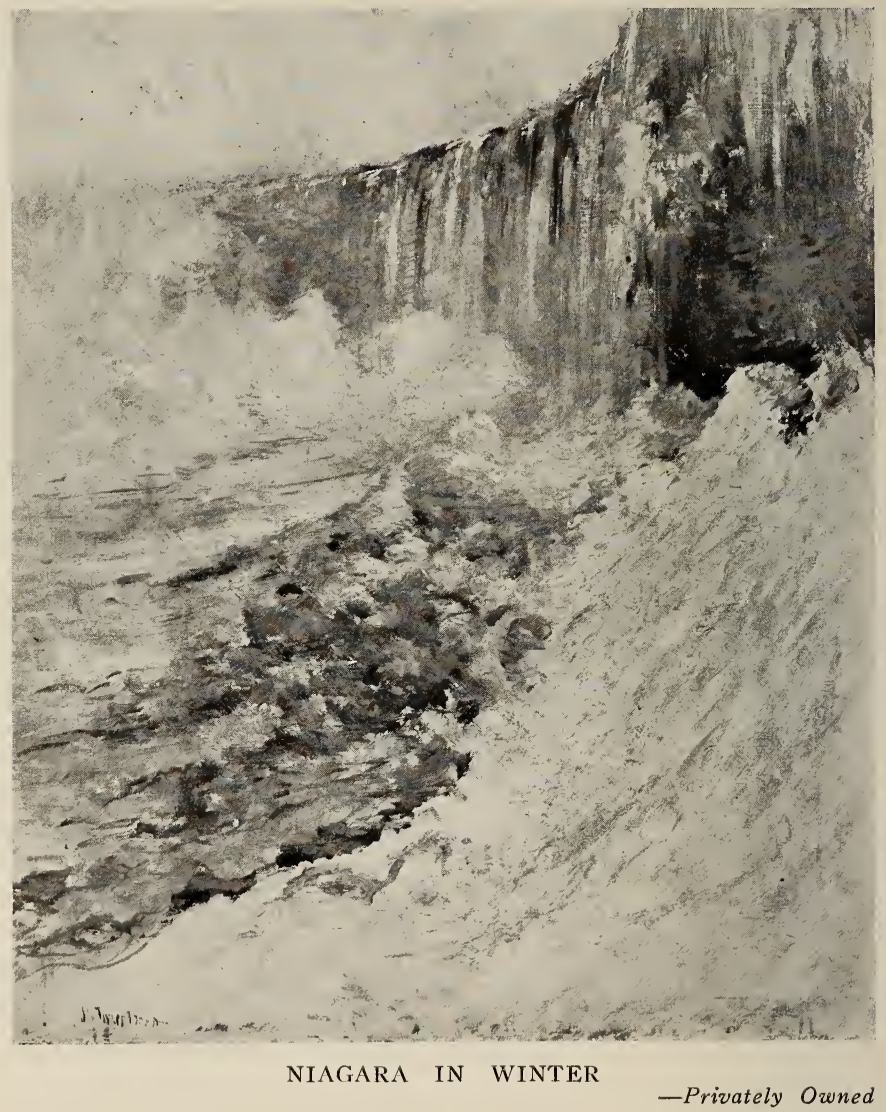




\section{JOHN H. TWACHTMAN}

1853-1902

Born, Cincinnati, Ohio, August 4, 1853; died at his home, Gloucester, Mass., August 8, 1902. Pupil of Cincinnati School of Design under Frank Duveneck, with whom he later went to Venice. In 1876, went to Munich for two years under Lœfftz, later working at Academie Julien in Paris under Boulanger and Lefebvre. In 1879, elected member of the Society of American Artists, but withdrew and became a member of the Ten American Painters. His specialty was landscapes, based largely upon the work of the French tonalists and impressionists.

Represented in Metropolitan Museum, New York; Museum of Art, Detroit, Mich.; Art Museum, Worcester, Mass.; Carnegie Institute, Pittsburgh, $\mathrm{Pa}$; and in many other museums and private collections, including those of Charles L. Freer, Esq., Detroit, Mich.; Mrs. Charles Cary, Buffalo, N. Y.; Dr. Alexander Humphreys, New York; Alexander Morten, Esq,, New York; W. J. Johnson, Esq., Uniontown, Pa.; William T. Evans, Esq., New York; and Charles A. Platt., Esq., New York.

Awarded Medal, Columbian Exposition, Chicago, 1893; Webb Prize, Society of American Artists, 1888, for "Windmills", now owned by Smith College; Temple Gold Medal, Pennsylvania Academy of the Fine Arts, 1895; Honorable Mention, Carnegie Institute, 1899; Silver Medal, PanAmerican Exposition, Buffalo, 1901. 


\section{$\begin{array}{lllllllllllllllllll}T & H & E & & M & A & C & B & E & T & H & G & A & L & L & E & R & Y\end{array}$}

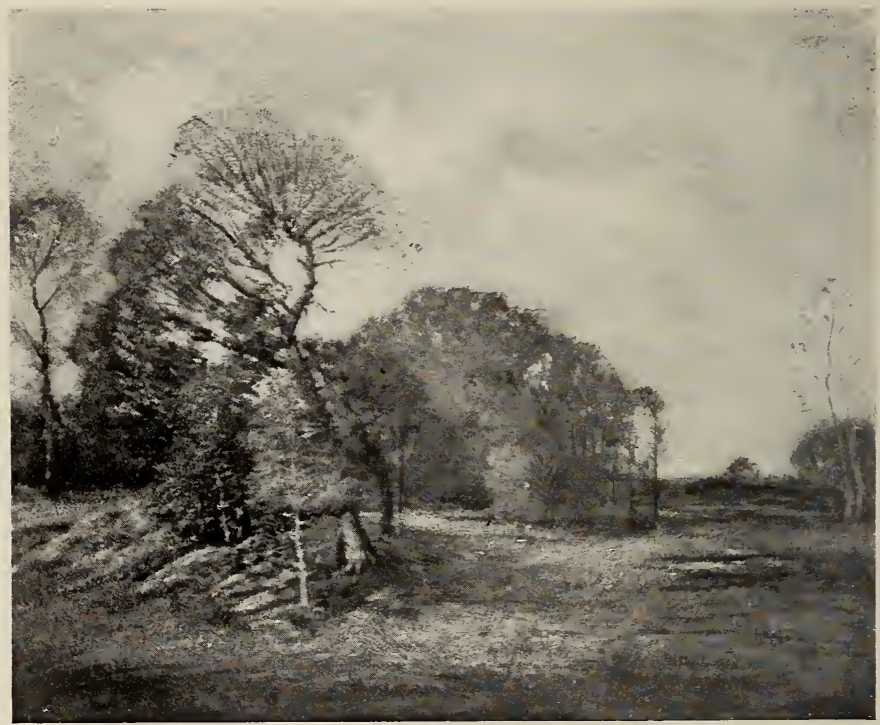

AUTUMN 


\section{ALEXANDER T. VAN LAER, N. A.}

Litchfield, Conn. Born Auburn N. Y., Feb. 9, 1857. Pupil of National Academy of Design and R. Swain Gifford, New York; George Poggenbeek in Holland. Elected Associate, National Academy of Design, 1901; Academician, 1909. President American Water Color Society; Faculty of Schools of National Academy of Design; Member New York Water Color Club; Artists' Fund Society; National Arts Club; Salmagundi Club; Lotos Club.

Represented in Lotos Club Permanent Collection; Brooklyn Institute Museum; National Gallery, Washington, D.C.; National Arts Club, New York; Public Museum, Montclair, N. J.; St. Louis Club, St. Louis, Mo.

Awarded Bronze Medal, Charleston Exposition, 1902; Gold Medal, St. Louis Exposition, 1905. 


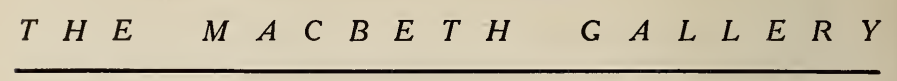

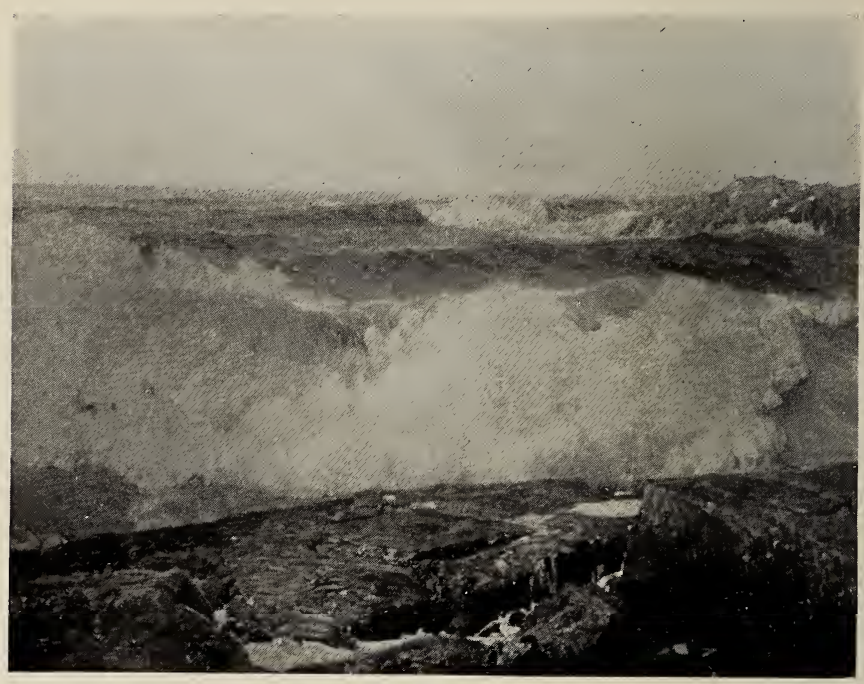

COAST OF CAPE ANN 
FREDERICK J. WAUGH, N. A.

Montclair, New Jersey; Born, Bordentown, New Jersey, Sept. 13, 1861. Son of S. B. Waugh, portrait painter. Pupil of Pennsylvania Academy of the Fine Arts; Julien Academy, Paris. Member of the National Academy of Design, Municipal Art League, National Arts Club, Lotos Club, Salmagundi Club, New York; Bristol Academy of Fine Arts, Bristol, England.

Represented in the National Gallery of Art, Washington, D. C.; Metropolitan Museum of Art, New York; Brooklyn Institute of Arts and Sciences; Montclair Art Association, Montclair, N. J.; Art Institute of Chicago; Toledo Art Museum, Toledo, Ohio; Museum Association, Newark, N. J.; National Arts Club, New York; Permanent Collection, Bay City, Mich.; Dallas Art Association, Dallas, Texas; Walker Art Gallery, Liverpool, England; Durban Municipal Art Gallery, South Africa; Philadelphia Art Club; Pennsylvania Academy of the Fine Arts, Philadelphia, $\mathrm{Pa}$.

Awarded Thomas B. Clarke Prize, National Academy of Design, 1910; Gold Medal, International Exposition, Buenos Aires, 1910; Norman Wait Harris Bronze Medal, Art Institute of Chicago, 1912. 


\section{$\begin{array}{llllllllllllllllll}T & H & E & & M & A & C & B & E & T & H & G & A & L & L & E & R & Y\end{array}$}

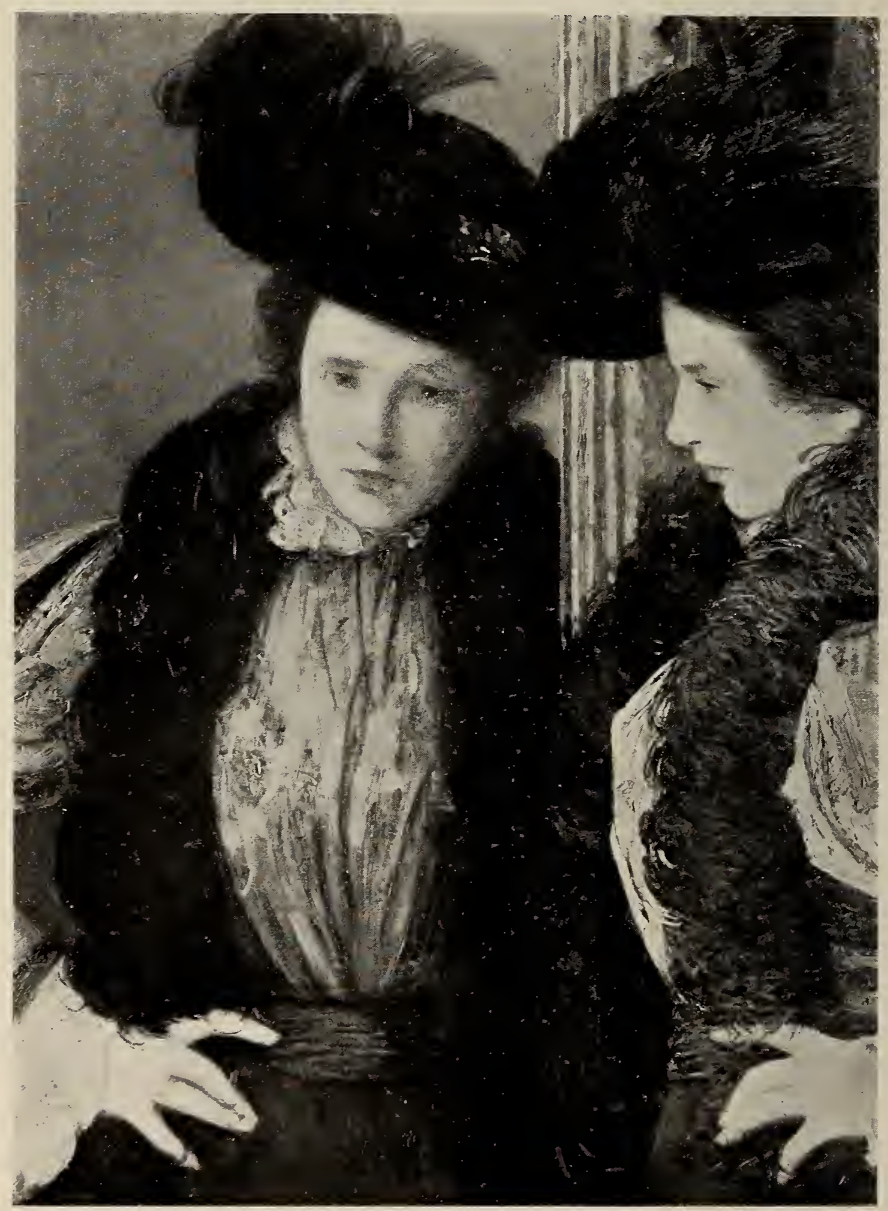

THE GREEN BODICE

- Metropolitan Museum 


\section{J. ALDEN WEIR, N. A.}

New York City. Born, West Point, New York, 1852. Studied with his father, Robert W. Weir, and with Gérome in Paris. Member of the $\mathrm{Na}$ tional Academy of Design, the Ten American Painters, American Water Color Club, New York Etching Club, Artists' Aid Society, Century Association, and the National Institute of Arts and Letters, New York.

Represented in the Metropolitan Museum of Art, New York; National Gallery, Washington, D. C.; Pennsylvania Academy of the Fine Arts, Philadelphia; Albright Art Gallery, Buffalo, New York; Rhode Island School of Design, Providence, Rhode Island; Cincinnati Museum Association; Art Institute of Chicago.

Honorable Mention, Salon, Paris, 1882; Silver and Bronze Medals, Exposition Universelle, Paris, 1900; Gold Medal, Pan-American Exposition, Buffalo, 1901; Gold and Silver Medals, Universal Exposition, St. Louis, 1914; Inness Gold Medal, National Academy of Design, New York, 1906; Prize, Boston Art Club; Prize, American Art Association, New York; Temple Gold Medal, Pennsylvania Academy of the Fine Arts, Philadelphia, 1905; Lippincott Prize, Pennsylvania Academy of the Fine Arts, 1910; Norman Wait Harris Silver Medal, Art Institute of Chicago, 1912. 


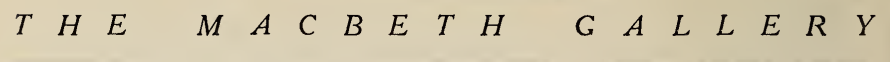

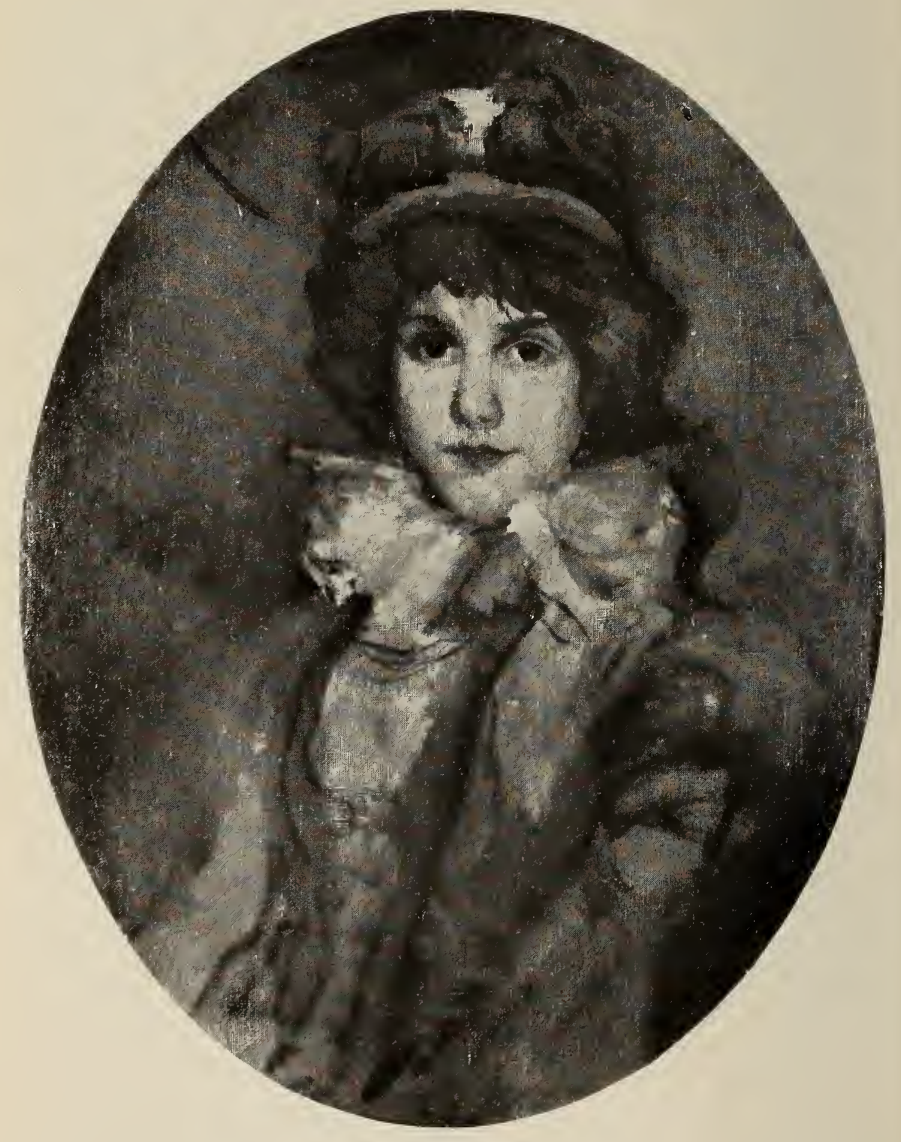

BLUE BONNET

- Privately Ozened 


\section{JAMES A. McNEILL WHISTLER 1834-1903}

Born, Lowell, Mass., 1834; died, Chelsea, London, 1903. Lived in Russia from eighth to fifteenth year. Returned to America in 1849; entered West Point, 1851, but was not graduated. Was connected with Coast Survey in Washington. In 1855, went to England, and shortly after moved to Paris, studying under Glyer. Exhibited in Royal Academy in 1859 for first time. Removed to London in 1863. Member, Sociéte Nationale des Beaux Arts, Paris; Chevalier (1889), Officer (1891) of the Legion of Honor; Chevalier, Order of St. Michael, Bavaria; Hon. Mem. Royal Academy, Bavaria; Hon. Mem. Royal Academy, Dresden; President, International Society of Sculptors, Painters and Gravers, London; President, Royal Society of British Artists; Hon. Mem. Royal Acad. of St. Luke, Rome; Commander of Order of the Crown of Italy; Hon. Mem. Royal Scottish Academy.

Represented in Glasgow Museum; Rijks Museum, Amsterdam; Dublin Gallery; British Museum; Bibliotheque Nationale, Paris; Venice Academia; Dresden Gallery; Luxembourg, Paris; Wilstach Gallery, Philadelphia, Pa.; Carnegie Institute, Pittsburgh; Metropolitan Museum; Museum of Fine Arts, Boston, Mass.; Art Institute of Chicago; Hackley Gallery, Muskegon, Mich.; Freer Collection, Detroit, Mich.

Awarded Gold Medal, Amsterdam, 1863; Medal of the Third Class, Paris Salon, 1883; Medal of the First Class, Munich, 1889; Gold Medal, Antwerp, 1889; Gold Medal, Exposition Universelle, Paris, 1889; Medals (painting and etching), World's Columbian Exposition, Chicago, 1893; Temple Gold Medal, Pennsylvania Academy of the Fine Arts, 1894; Gold Medal, Antwerp, 1895; Grand Prix (painting) and Grand Prix (etching), Exposition Universelle, Paris, 1900; Gold Medal (painting and etching), Pan-American Exposition, Buffalo, 1901, Honorary Degree of Doctor of Literature, Glasgow University, 1903. 


\section{$\begin{array}{lllllllllllllllllll}T & H & E & & M & A & C & B & E & T & H & & G & A & L & L & E & R & Y\end{array}$}

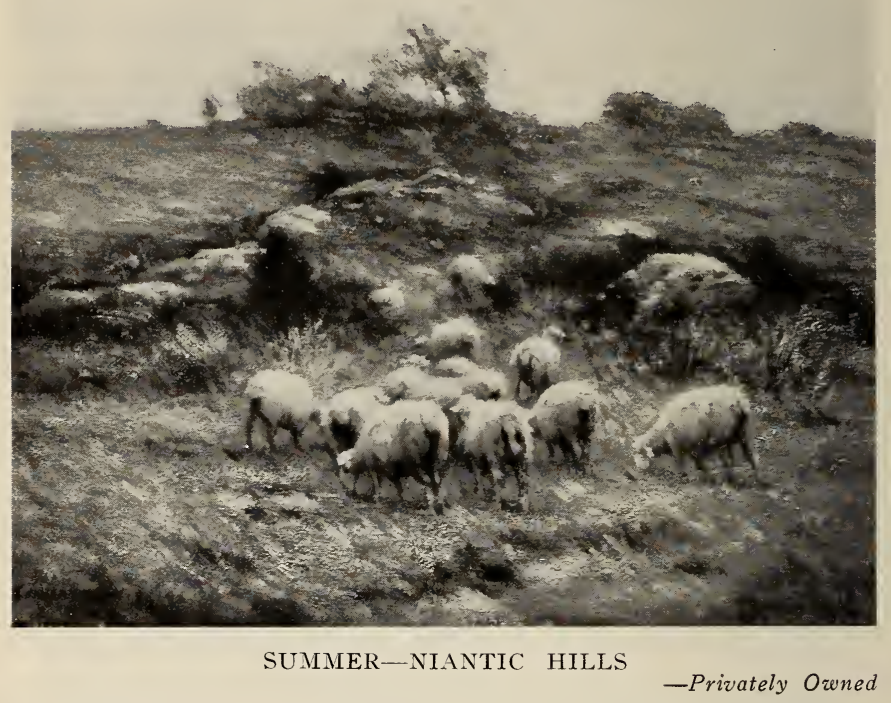




\section{CARLETON WIGGINS, N. A.}

New York City and Lyme, Conn. Born Turner's, Orange County, N. Y., March 4, 1848. Pupil of National Academy of Design and of George Inness, New York. Elected Associate, National Academy of Design, 1890; Academician, 1906. Member of Society of American Artists, 1887; American Water Color Society; Salmagundi Club; Lotos Club; Brooklyn Art Club; Artists' Fund Society; Artists' Aid Society.

Represented in Metropolitan Museum, New York; Lotos Club, New York; Hamilton Club, Brooklyn; Corcoran Gallery, Washington; National Gallery, Washington; Institute of Arts and Sciences, Brooklyn, N. Y.

Awarded Gold Medal, Prize Fund Exhibition, New York, 1894; Bronze Medal, Pan-American Exposition, Buffalo, 1901. 


\section{$\begin{array}{llllllllllllllllll}T & H & E & & M & A & C & B & E & T & H & G & G & L & L & E & R & Y\end{array}$}

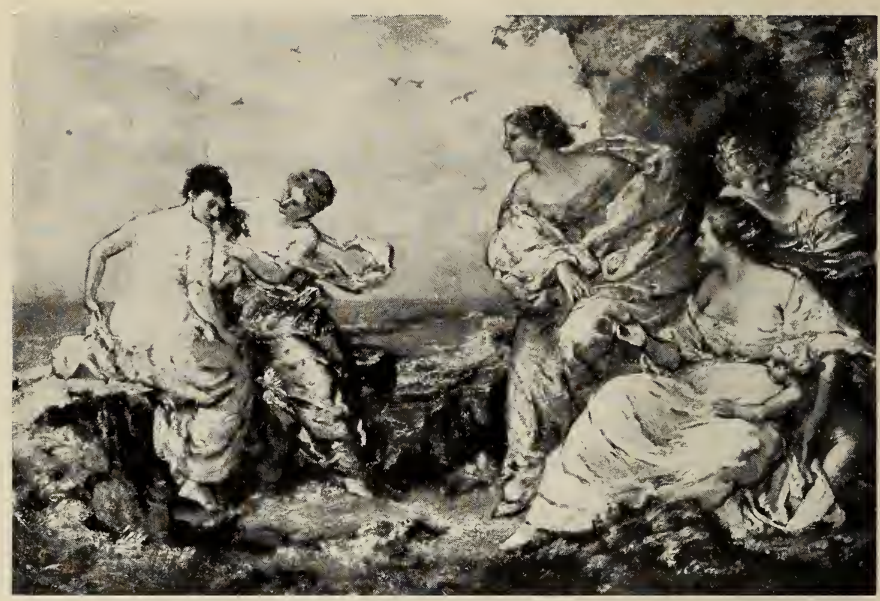

SUMMER

-Privately Owned 


\section{F. BALLARD WILLIAMS, N. A.}

New York City. Born, Brooklyn, N. Y., Oct. 21, 1871. Pupil of Cooper Union and National Academy of Design. Elected Associate, National Academy, 1907; Academician, 1909. Member New York Water Color Club, Society of Men Who Paint the Far West; Lotos Club, Salmagundi Club, National Arts Club.

Awarded Bronze Medal, Pan-American Exposition, Buffalo, 1901; Inness Prize, Salmagundi Club, 1907; Isidore Gold Medal, National Academy of Design, 1909.

Represented in National Gallery, Washington; Metropolitan Museum; Albright Art Gallery, Buffalo; Institute of Arts and Sciences, Brooklyn, N. Y.; Public Museum, Atlanta, Ga.; Hackley Gallery, Muskegon, Mich. 
$\begin{array}{llllllllllllllllll}T & H & E & & M & A & C & B & E & T & H & G & G & L & L & E & R & Y\end{array}$

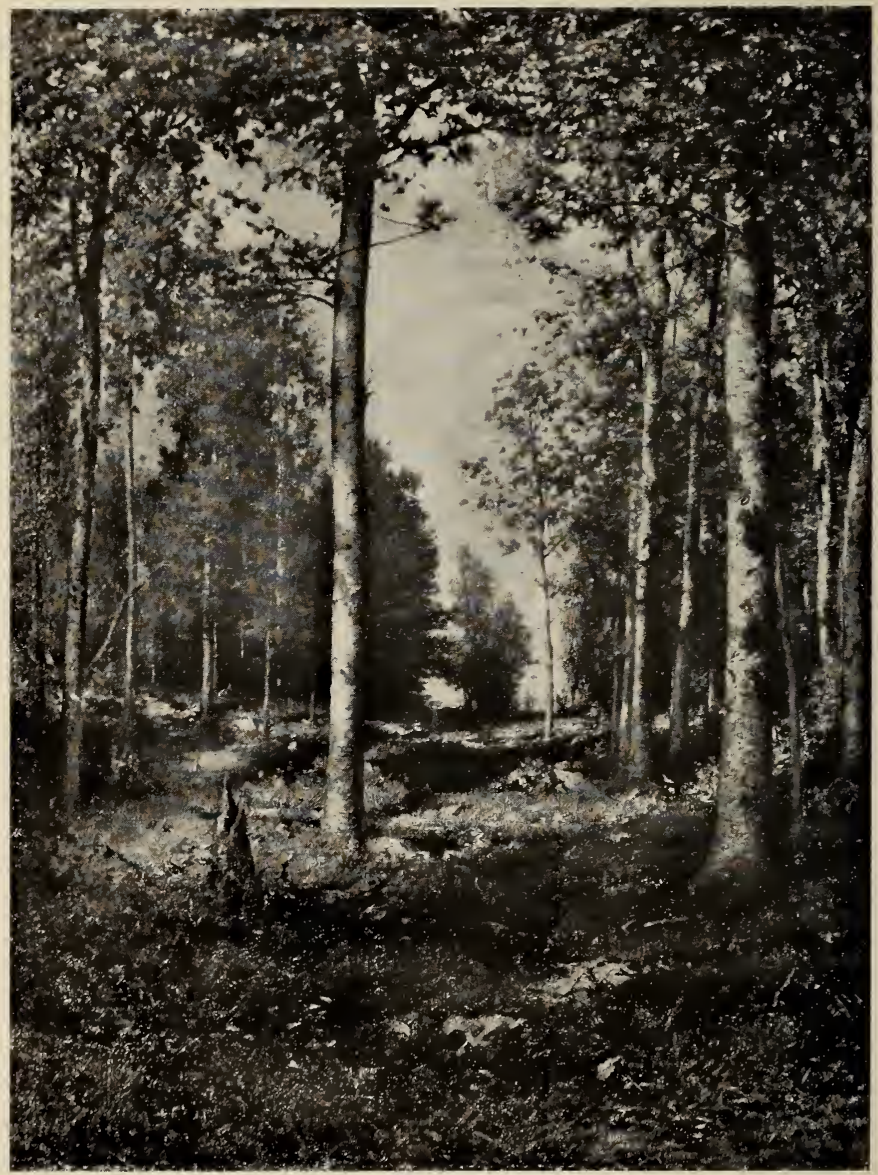

IUTUMN IN THE WOODS -Privately Owned 


\begin{tabular}{llllllllllllllllll}
$T$ & $H$ & $E$ & $M$ & $A$ & $C$ & $B$ & $E$ & $T$ & $H$ & $G$ & $A$ & $L$ & $L$ & $E$ & $R$ & $Y$ \\
\hline
\end{tabular}

\section{ALEXANDER H. WYANT}

\section{$1836-1892$}

Born, Defiance, Ohio, 1836. Exhibited great talent for drawing as a boy. In the early fifties, removed to Cincinnati, where he saw his first paintings. When about twenty years old, went to New York and showed sketches to George Inness, who encouraged him to continue. Went to Carlsruhe and studied under Hans Gude, to whom can be traced his emphasis of form and construction, and dignity of composition. Subsequently studied in London, returning to New York about 1865. Went west with government exploring expedition, privations and accidents of which resulted in partial paralysis, so that, after 1869 , he was compelled to paint with his left hand. Painted for many years in Keene Valley, Adirondacks, and later in Arkville, in the Catskill Mountains, where most of his best work was done. He was a semi-invalid all the latter part of his life, and died in New York in 1892.

First exhibited in the National Academy, New York, in 1865. Elected an Associate of the Academy in 1868, Academician, 1869, and was one of the founders of the American Society of Painters in Water Colors. He is represented in most of the important museums and private collections throughout the country. 





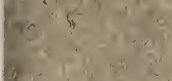

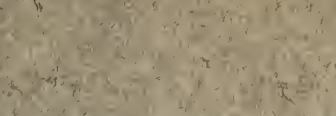

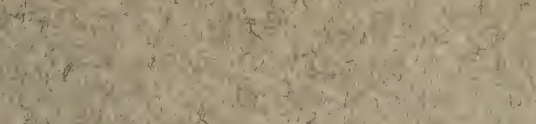

tin is in

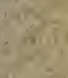

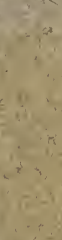

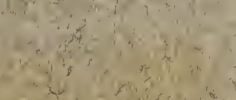

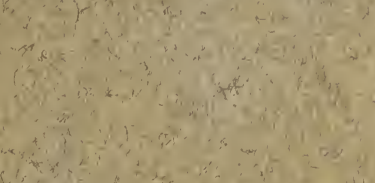

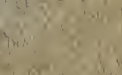

$x+3=3$

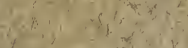

$8=\sqrt{2}$

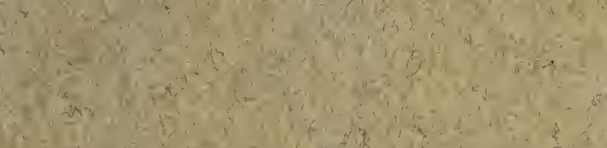

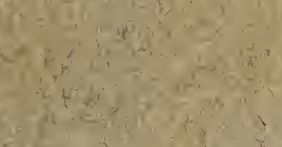
$\left.f^{f}+2\right\} ?$

$\therefore \sin ^{2}-5$

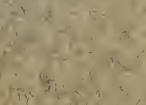

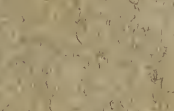

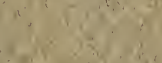

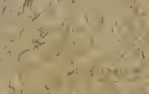

(4):

6

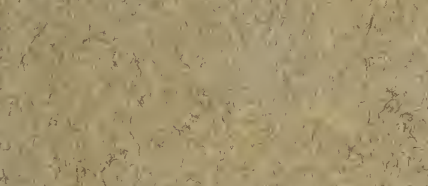

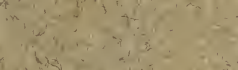

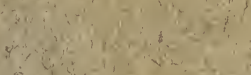

istio.

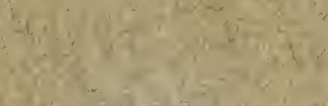

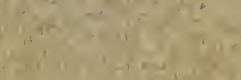

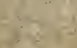

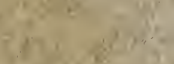
67.2 .8 (1)

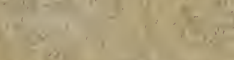
asil

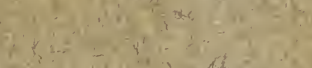
$x-2, x=1$

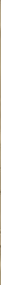




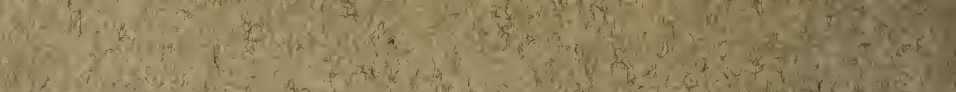

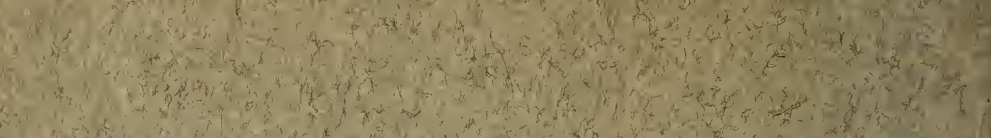

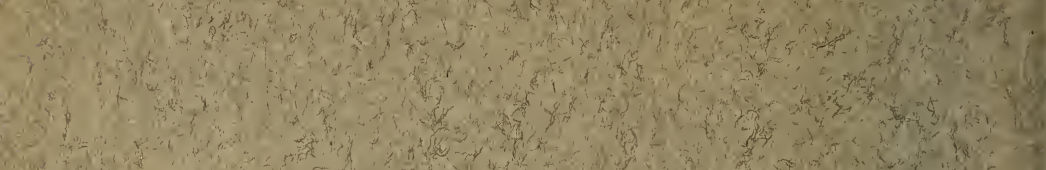
6ing

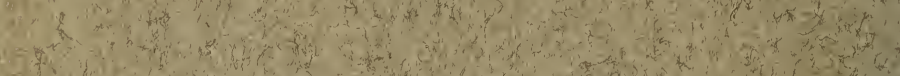
(8) 3040 (3)

(14)

(19)

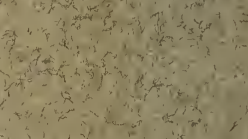
56

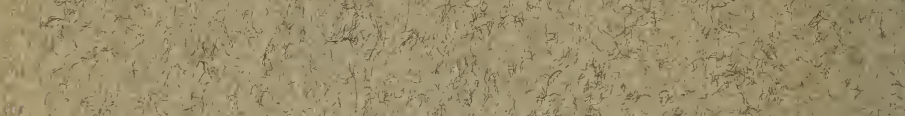
(46) $x^{3}$, 150.

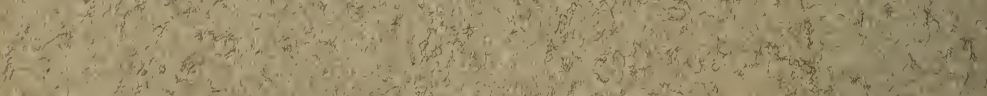

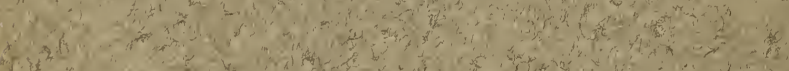

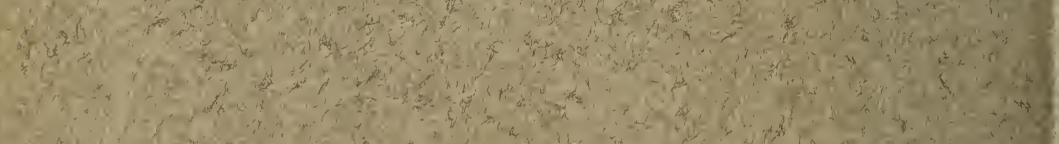

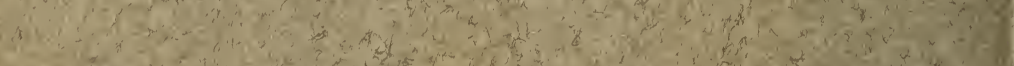

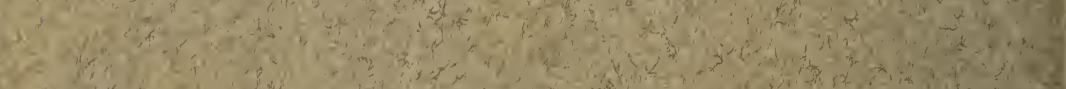

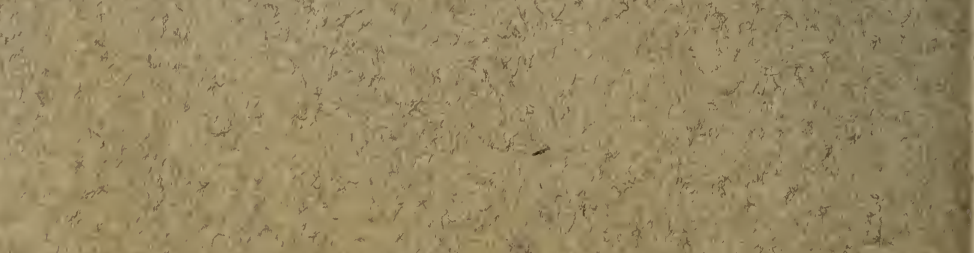

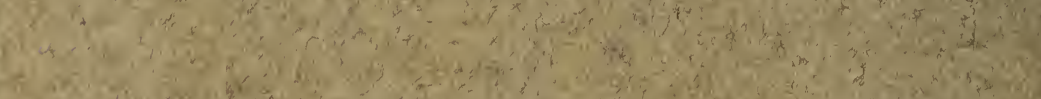

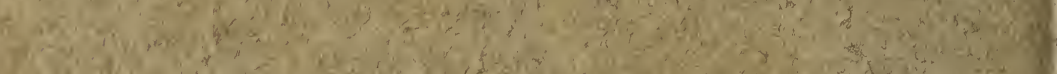

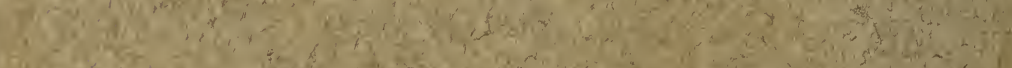





